Miguel Ferreira Mouta Júnior

\title{
Aumento da sobrevida e diminuição da expressão de actina e fibronectina no timo, na sepse tratada com sobrenadante de explante de timo
}

Dissertação apresentada à Faculdade de Medicina da Universidade de São Paulo para obtenção do título de Mestre em Ciências.

Área de concentração: Alergia e Imunopatologia

Orientador: Prof. Dr. Luiz Vicente Rizzo

SÃO PAULO 
Dedicado aos meus Pais e a minha Irmã 


\section{AGRADECIMENTOS}

O autor agradeçe as seguintes pessoas:

Drs Luiz V Rizzo, Flávio Monteiro B Maciel, Jorge Kalil (INCOR), pela orientação acadêmica e crítica científica .

Dra Maria Regina Catarino, Kléber Simões Espírito Santo-médico, ( IAL), pela realização do estudo imunohistoquímico e observações pertinentes.

Dra Silvia Massironi e Bioteristas: Renaide Rodrigues Ferreira, Rosália Regina de Lucca (ICB-USP), pela facilitação dos procedimentos com animais.

Bibliotecárias: Maria José de Jesus Carvalho (ICB-USP) e Marinalva de Souza Aragão (FMUSP), pelo especial apoio na montagem do texto. 
"Bernard avait remain... le microbe n'est rien, c'est le terrain qui est tout." "Bernard está certo...

o micróbio não é nada, o terreno é que é tudo"

Pasteur, em seu leito de morte. 


\section{NORMALIZAÇÃO ADOTADA}

Esta dissertação está de acordo com as seguintes normas, em vigor no momento desta publicação:

Referências: adaptado de International Committee of Medical Journals Editors (Vancouver).

Universidade de São Paulo. Faculdade de Medicina, Servço de Biblioteca e Documentação. Guia de apresentação de dissertações, teses e monografias. Elaborado por Anneliese Carneiroda Cunha, Maria Juliade A. L. Freddi, Maria F. Crestana, Marinalva de Souza Aragão, Suely Campos Cardoso, Valéria Vilhena, 2 ed. São Paulo: Serviço de Biblioteca e Documentação; 2005.

Abreviatura dos títulos dos periódicos de acordo com List of Journals Indexed in Index Medicus. 


\section{SUMÁRIO}

Listas de Siglas, Abreviaturas e Símbolos

Listas de Ilustrações

Listas de Tabelas

Resumo

Summary

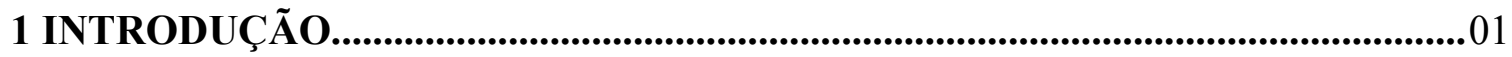

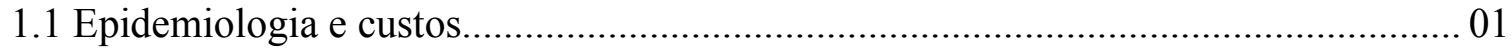

1.2 Evolução do conceito clínico de sepse associada ao trauma.....................................02

1.3 Aspectos relevantes da resposta imune no trauma e no desenvolvimento da sepse....04

1.4 Imunodepressão e apoptose de linfócitos na sepse............................................... 08

1.5 Papel de proteínas do citoesqueleto e da matriz extracelular na sobrevivência celular

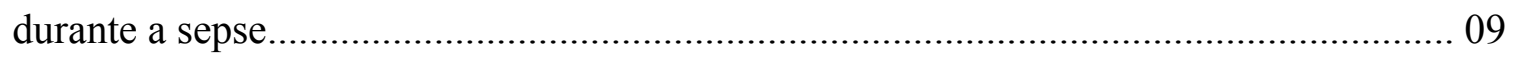

1.6 Reversão de apoptose na sepse e Substâncias de Sobrevivência Celular....................11

1.7 Experiência clínica com hormônios tímicos.......................................................... 13

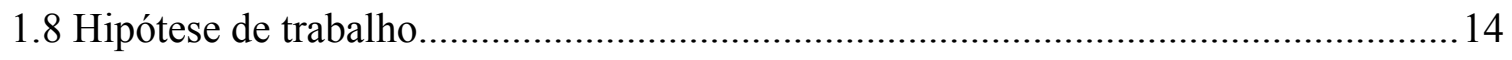

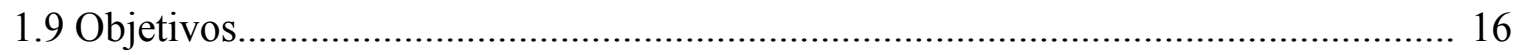

2 MATERIAIS E MÉTODOS.......................................................................... 17

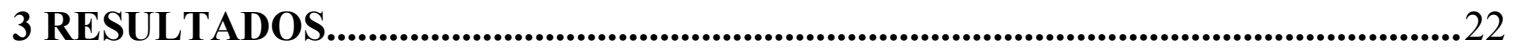

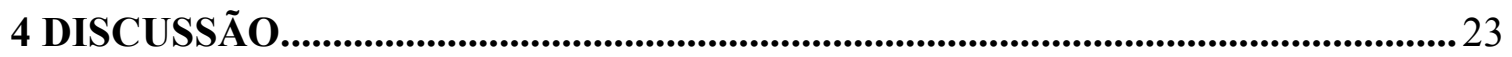

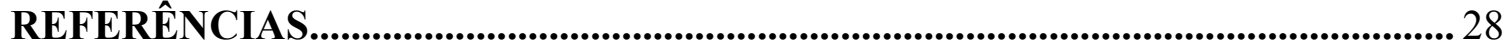

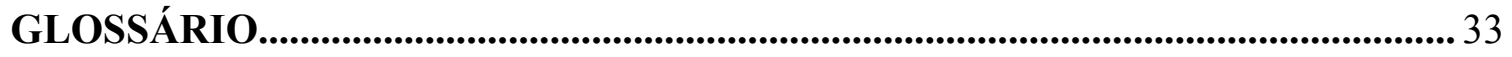

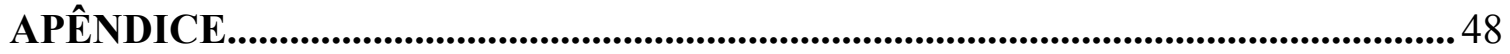




\section{LISTA DE ILUSTRAÇÕES}

Figura 1 - Apresentação esquemática demonstrando as vias de sinalização e funções relacionadas com enzima Akt-PKB

Figura 2 - Apresentação esquemática mostrando que substancias sem efeitos Anti-inflamatórios bloqueiam a aglomeração de actina devido a ação sobre mecanismos de sobrevivência celular 16

Figura 3- Cultura de explante de timo de rato Wistar recém-nato,após 24 horas de cultivo, em microscópio de inversão, com aumento de 40 vêzes. A área demarcada mostra um aglomerado de células

Figura 4- Cultura de explante de timo de rato Wistar recém-nato, após 48 horas de cultivo, em microscópio de inversão, com aumento de 40 vezes. Pode se observar a maior confluência da cultura, em relação a mostrada pela figura 3

Figura 5- Expressão de actina (aumento 400x). As setas brancas mostram feixes em marrom, correspondentes a áreas de expressão de actina. $\mathrm{O}$ tecido que não apresentou reação imunohistoquímica para a actina, foi corado com hematoxilina-eosina.

Figura 6- Expressão de fibronectina (aumento 100x). As setas indicam pontos marrons correspondentes à presença de fibronectina. (No grupo "sobrenadante", a seta mostra fibronectina associada à parede de um vaso. $\mathrm{O}$ tecido que $\mathrm{n} \sim$ qo qpresentou reação imunohistoquímica para a fibronectina, foi corado com hematoxilina-eosina. 26

Figura 7- Gráfico mostrando o percentual de probabilidade de sobrevivencia em ratos Wistar acumulada até o quinto dia após ligadura e punção cecal, com os tratamentos realizados neste estudo . As linhas "Wichterman" e "Miguel" referem-se a controles com sepse apenas, realizados no modelo original, e pelo autor da 


\section{LISTA DE TABELAS}

Tabela 1- Probabilidade de Sobrevida Acumulada Segundo Grupo (\%)................................... 27 


\section{LISTA DE SIGLAS, ABREVIATURAS E SÍMBOLOS}

Act - Actina

ATP - Trifosfato de adenosina

Akt-PKB - Proteína quinase B

Balb-C - Camundongo nude

BCL2 - Proteína 2 de células de linfoma B

C5a - Complemento C5a

CD4 - Conjunto de diferenciação 4

Cdk - Quinase dependente de ciclina

$\mathrm{CO}_{2}$ - Dióxido de carbono

DNA - Ácido desoxirribonucleico.

ERK 1/2 - Quinase extracelularmente regulada 1/2

Fn - Fibronectina

EUA - Estados Unidos da América

FAS-L - Ligante de FAS

FMUSP - Faculdade de Medicina da Universidade de São Paulo

HLA - Antígeno leucocitário humano

$\mathbf{H}_{2} \mathbf{O}_{2}-$ Peróxido de Hidrogênio

IAL - Divisão de Patologia do Instituto Adolfo Lutz - São Paulo.

ICB-USP - Instituto de Ciências Biomédicas da Universidade de São Paulo

IL - Interleucina

INCOR - Instituto do Coração - São Paulo

Inf- $\boldsymbol{\gamma}$ - Interferon gama

mmHg - milímetros de mercúrio

$\mathbf{O}_{2}$-Oxigênio

OMS - Organização Mundial de Saúde 
PBS - Solução tampão de fosfato

PGE2 - Prostaglandina E2

PI3K - Fosfatidilinositol 3-fosfato

SICS - Síndrome da Imunodeficiência Combinada Severa

SPSS - Pacote estatístico para ciências sociais

Tb4 - Timosina B4

Th $-\mathrm{T}$ auxiliador

TG - Transglutaminase tecidual

TNF- $\alpha$ - Fator de necrose tumoral alfa

TGF- $\beta$ - Fator transformante de crescimento beta

USA - Estados Unidos da América

${ }^{\circ} \mathbf{C}$ - Graus centígrados

g- Grama

$>-$ maior que

$<-$ menor que 


\section{RESUMO}

Mouta Júnior MF. Aumento da sobrevida e diminuição da expressão de actina e fibronectina no timo, na sepse tratada com sobrenadante de explante de timo [Dissertação (Mestrado em Ciências)]: São Paulo - Faculdade de Medicina da Universidade de São Paulo; 2007.

O timo secreta substâncias promotoras da sobrevivência de linfócitos e hormônios ligados à dinâmica do citoesqueleto. Esses agentes são produzidos em grande quantidade pelo animal recém-nato, e apresentam efeito homeostático sobre a população de linfócitos $\mathrm{T}$ circulantes, por toda a vida. Na sepse, a atrofia dos órgãos linfóides, o surgimento de acúmulos de actina intersticial, e a diminuição dos níveis de fibronectina plasmática guardam relação com a mortalidade. O trabalho aqui descrito procurou detectar o efeito do sobrenadante de cultura de timo de rato Wistar neonato, saudável, sobre a mortalidade e as expressões simultâneas de actina e fibronectina em timos de ratos Wistar adultos submetidos a sepse peritoneal. Foi constatada uma diminuição na expressão de actina e de fibronectina no interstício de timos de ratos Wistar adultos sépticos, tratados com a aplicação intraperitoneal do sobrenadante de explante de timo de ratos neonatos. Tal efeito provocou um aumento da sobrevivência semelhante ao tratamento com meio de cultura apenas ( sem explante), contudo houve uma notável melhora dos sinais clínicos . Não houve qualquer efeito anti-inflamatório, com o tratamento com o sobrenadante, sobre inflamação periférica em animais saudáveis submetidos a injeção intramuscular de glutaraldeído, o que afastou a hipótese de influência sobre a enzima tranglutaminase tecidual, ativada em estados inflamatórios, e responsável pela aglomeração intersticial, da actina originada de células lesadas. $\mathrm{O}$ autor concluiu que os efeitos observados pelo tratamento com sobrenadante de cultura de timo de animal recém-nato, podem ser atribuídos a estimulação de mecanismos promotores da integridade celular, frente aos estresses químicos vigentes no meio interno, durante a sepse. $\mathrm{O}$ autor sugere que a observação simultânea de actina e fibronectina no timo pode auxiliar nos estudos de tratamentos experimentais da sepse.

Descritores: 1.Sepse 2.Ferimentos e lesões 3.Microfilamentos 4.Timo 5.Apoptose 6.Ratos Wistar 


\section{SUMMARY}

Mouta Junior MF. Increase in survival rate and decrease in the expression of actin and fibronectin of the thymus in sepsis treated with supernatant from thymus explant [Dissertation (Masters Thesis)]: São Paulo- Faculty of Medicine of the University of São Paulo; 2007.

The response of septic adult Wistar rats submitted to treatment with supernatant from the culture of thymus of healthy newly-born Wistar rats were observed. Although there has not been significant reduction in mortality compared relation to treatment with culture medium only (without explanted), it was possible to observe a rapid improvement in the clinical conditions and a lower agglomeration of actin and fibronectin in the thymus of treated animals. We did not observe any anti-inflammatory effect of the supernatant in animals with paw inflammation exclusively, which averted the modulation of the Tissue Transglutaminase Enzyme, agglomerator of the actin released by diseased cells. The author concludes that the treament of sepsis with supernatant stimulated survival in thymus, and suggests that the immuno-hystochemical study of actin and fibronectin in the thymus isa useful method in the analysis of experimental treatments of sepsis.

Descriptors: 1.Sepsis 2.Wounds and injuries 3. Microfilaments 4.Thymus gland 5.Apoptosis 6.Rats Wistar 


\section{INTRODUÇÃO}

\section{$\underline{1.1 \text { Epidemiologia e Custos }}$}

Dentre os pacientes que desenvolvem complicações sépticas, após internação hospitalar por trauma ou injúria tecidual, existe uma percentagem que desenvolve falência de múltiplos órgãos e sistemas, com elevada taxa de mortalidade. Sepse, entendida no contexto de uma resposta inflamatória sistêmica, se correlaciona, em sua intensidade, não apenas com a gravidade da injúria tecidual, mas, também, com a mortalidade dos pacientes que a desenvolvem (1).

Segundo a Organização Mundial de Saúde, sepse constituiu a $12^{\mathrm{a}}$ causa de morte nos Estados Unidos da América sendo, anualmente previsto, um mínimo de 210.000 óbitos com este diagnóstico, naquele país (2). Estatísticas privadas mostram um aumento da incidência de episódios de sepse severa nos hospitais dos EUA, com a referência de 660.000 casos no ano de 2003, junto com a taxa de mortalidade de 18\% (3). Conforme estudos acadêmicos de 1997 e de 2001, e não obstante os constantes avanços nas técnicas cirúrgicas e de terapia intensiva, a taxa de mortalidade permanece na mesma grandeza estatística, já há vinte anos, alcançando entre 23 e 34\% dos pacientes com o diagnóstico de sepse (4).

No Brasil, o Ministério da Saúde refere que, durante o ano de 2005, 30,27\% dos óbitos ocorridos em áreas com 100.000 habitantes, deveu-se a acidentes de trabalho e outras causas violentas (sem dados quanto a internação hospitalar) (5).

A maioria das mortes, conseqüentes ao trauma, em serviços de terapia intensiva nas Américas, é atribuída a infecção, que, em $80 \%$ dos casos, é acompanhada de falência de múltiplos órgãos e sistemas. Embora sem índices com o diagnóstico explícito de sepse, a OMS enquadra, no Brasil, o diagnóstico de trauma somado aos outros diagnósticos de óbito por causas violentas (intoxicações e envenenamentos) na categoria de causas de mortes externas. Segundo esses estudos, tais causas externas representam cerca de $6 \%$ das hospitalizações no sistema público de saúde, que acarretam, porém, um custo diário $60 \%$ superior às demais causas de internação (6). 


\subsection{Evolução do conceito clínico de sepse associada ao trauma}

Fracastoro (1478-1553) foi o primeiro a conceber a idéia de que corpos minúsculos poderiam ser passados entre as pessoas e causar infecção (7). A comprovação da causalidade microbiana de doenças foi posteriormente realizada por Pasteur e Koch (186065), e consubstanciada pelas técnicas de antissepsia, desenvolvidas pelos contemporâneos Semmelweis, Lister, Halstead e Von Bergmann, resultando em uma grande redução na incidência de infecções em ferimentos. No entanto, alguns renomados cirurgiões daquela época não conseguiram repetir o sucesso dos procedimentos preconizados. Por exemplo, Theodor Billroth, em 1871, escreveu o trabalho "febre séptico-traumática e septicemia", no qual priorizava a relação entre injúria tecidual e manifestações sistêmicas da doença (não obstante ter aplicado os métodos de Lister) (8). Desde então, a dificuldade de identificação de sinais clínicos que permitissem diferenciar os quadros inflamatórios dos infecciosos, e também, a confusão entre termos como inflamação, sepse e septicemia (presença de microorganismo no sangue), seguiram causando obstáculo à abordagem científica. Investigações clínicas e experimentais, ao longo do século XX, levaram a maior distinção entre os componentes da fisiopatologia do trauma e da sepse. Dentre essas observações, podemos encontrar dois eventos com maior impacto: 1) a definição da Reação Sistêmica Inespecífica de Stress, por Hans Selye (1936) (9), que caracteriza o papel modulador dos hormônios corticóides sobre o metabolismo e a resposta imune, como modo de adaptação do organismo a qualquer situação de emergência, não necessariamente ligada a infecção.2) a identificação de um estado inflamatório pulmonar, sem causa microbiana, conseqüente à hemorragia por ferimento de guerra ("Pulmão de Choque" ou "Pulmão de Da Nang", 1967) (10). Em 1991, um consenso entre a Society of Critical Care Medicine e a American College of Chest Physicians, padronizou definições relacionadas à sepse e inflamação póstrauma, as quais apesar de outras mais recentes, permanecem mundialmente utilizadas (11).

Os princípios do consenso de 1991 fundamentam-se em que o trauma e o estresse cirúrgico - bem como as infecções - iniciam mudanças na função imune que não se limitam à inflamação local, ou seja, agem de modo sistêmico. A intensidade dessas reações pode variar desde alterações na composição sérica, pouco perceptíveis clinicamente, até respostas inflamatórias severas, que podem culminar no colapso circulatório, Síndrome da 
Angústia Respiratória, coagulopatias, ou em um quadro misto envolvendo falência de múltiplos órgãos e sistemas. A resposta inflamatória inicial do organismo foi então denominada Resposta Inflamatória Sistêmica, e passou a ser definida como a presença de dois ou mais dos seguintes sinais: temperatura $>38^{\circ} \mathrm{C} \mathrm{ou}<36{ }^{\circ} \mathrm{C}$, freqüência cardíaca $>90$ batimentos por minuto, freqüência respiratória $>20$ incursões por minuto ou pressão parcial arterial de $\mathrm{CO}_{2}<32 \mathrm{mmHg}$, Hemograma com presença de mais de 12.000 ou menos de 4.000 leucócitos por $\mathrm{ml}$ de sangue periférico ou, presença de $>10 \%$ de formas leucocitárias imaturas. Essa definição permite a identificação precoce de um contexto orgânico básico, em pacientes que, acometidos de trauma ou processos infecciosos severos, possuem maiores chances de desenvolverem uma, ou mais, das complicações citadas.

Apesar da grande ativação das respostas inflamatórias iniciais, a susceptibilidade à infecção nos pacientes acometidos por trauma e/ou sepse está associada à falha do sistema imune, que surge em 12 a 24 horas após o evento agressor. Essa fase se caracteriza pelo surgimento de anergia linfocitária (entendida como pouca resposta proliferativa a agentes mitógenos), e diminuição da imunidade celular do tipo tardio (12). Nesse período _ também chamado de fase anérgica _ a queda na contagem de linfócitos periféricos totais apresenta valor prognóstico, existindo, a partir do terceiro dia de trauma, uma correlação entre os níveis de linfopenia e o risco de complicações como: desenvolvimento de infecções secundárias, insuficiência de múltiplos órgãos e sistemas, e conseqüente óbito (13).

Assim, pode-se compreender o quadro de sepse como uma resposta inflamatória sistêmica, decorrente de infecção. Em outra seqüência, a presença da resposta inflamatória sistêmica, por causa infecciosa ou traumática, pode favorecer o estabelecimento ou o agravamento de uma infecção.

Tal conceito permite também concluir que, a situação de Resposta Inflamatória Sistêmica manifesta-se de modo coordenado, global e inespecífico, priorizando-se sobre as funções fisiológicas de rotina. Fica implícito, portanto, que tal imposição é capaz de atingir vários níveis de organização biológica. 


\subsection{Aspectos da resposta imune no trauma e no desenvolvimento da sepse}

Ao longo do processo de evolução das espécies, e, devido à possibilidade de infecção concomitante, o sistema imune desenvolveu-se junto com os mecanismos de reparação ao trauma (coagulação e cicatrização). Assim, é possível compreender o motivo pelo qual um mediador bioquímico pode desempenhar funções tanto imunológicas, como reparadoras. A ativação desses mecanismos moleculares, durante o processo inflamatório tecidual, se realiza por seqüência, seguindo as fases de: detecção, imobilização de agentes patógenos, destruição desses agentes (junto com o material orgânico inviável) e cicatrização. Qualquer falha na capacidade de detecção molecular da conclusão adequada, de alguma dessas fases, pode ocasionar a persistência de uma determinada etapa da resposta inflamatória. Tais distúrbios de regulação podem ser incapazes de abolir a resposta inflamatória original, e levar à permanência, ou mesmo ao excesso, de inflamação, seja ao nível local, ou, sistêmico. Os fatores controladores estão sujeitos a forte modulação do genótipo individual (polimorfismos), com influências já comprovadas, inclusive, do complexo principal de histocompatibilidade ( HLA) (14).

As alterações iniciais no local da lesão que ocorrem após o trauma são seguidas por uma diminuição da resposta do hospedeiro, que predispõe à infecção secundária. Essas mudanças incluem a ativação inicial de citocinas pró-inflamatórias, ativação do sistema complemento, ativação de fatores de coagulação e posterior produção de citocinas antiinflamatórias, com conseqüente diminuição da resposta imune do tipo celular. A maior produção de mediadores químicos pró-inflamatórios, como o fator de necrose tumoral alfa, interleucina-1 e interleucina-6, vistos na fase de resposta inflamatória sistêmica, precede, invariavelmente, a uma segunda fase com diminuição da produção de citocinas promotoras da imunidade celular (como interferon gama) junto ao aumento da quantidade de outros mediadores que inibem a resposta inflamatória, como interleucina-10 e fator transformante de crescimento beta. Adicione-se ao quadro a elevação dos níveis plasmáticos de hormônios corticóides, imunossupressores, mediada pelo sistema nervoso central, vigente na reação adaptativa de estresse. Essa fase contra-regulatória, denominada Síndrome da Resposta Antiinflamatória Compensadora (15), dirige-se à limitação da resposta imune do 
tipo celular e tem sido descrita como um estado de paralisia imunológica, considerada uma causa de suscetibilidade aumentada às infecções (16).

Além dos linfócitos, células pertencentes ao sistema imune inespecífico também sofrem disfunção na sepse. Tais células agem normalmente em um contexto geral de vigilância epidemiológica inespecífica, com importante papel no reconhecimento e resposta imediata aos fragmentos de células lesadas do hospedeiro, e de material exógeno. Tal defesa demanda maior reconhecimento de identidade molecular do agente invasor, sendo, portanto, desenvolvida de forma mais lenta.

Os eventos imunológicos inespecíficos mais expressivos, durante a resposta inflamatória, são aqui brevemente relacionados, conforme o tipo celular (17):

- Neutrófilos: após o trauma, os neutrófilos apresentam diminuição da quimiotaxia e da fagocitose, associadas à diminuição da capacidade de gerar radicais de oxigênio livre e das atividades fagocítica e bactericida. Entretanto, também levam à ativação das células endoteliais, precipitando complicações cardiovasculares e coagulação intravascular disseminada. Na vasculatura pulmonar causam reação inflamatória local, com formação de edema pulmonar e angústia respiratória, agindo sobre o endotélio por fatores como hipóxia, radicais de $\mathrm{O}_{2}$ livres, em conjunto aos macrófagos alveolares. Devido ao aumento da permeabilidade intestinal por neutrófilos locais ativados pela produção de radicais livres induzidas por isquemia, e pelo efeito da elastase sobre proteínas estruturais intercelulares, estão relacionados à translocação de bactérias do intestino delgado para o mesentério, as quais, deste ponto, partem para a disseminação sistêmica.

- Macrófagos: o trauma ou estresse diminuem de modo intenso a produção de granulócitosneutrófilos, em favor do aumento da monocitose. Os macrófagos, ativados por mediadores inflamatórios e lipopolissacáride bacteriano, tornam-se altamente bactericidas, com liberação de grandes quantidades de radicais livres de $\mathrm{O}_{2}\left(\mathrm{H}_{2} \mathrm{O}_{2}\right)$, e óxido nitrico. Um posterior estímulo estressor (hipotensão) pode hiperativar os macrófagos com liberação de Prostaglandina E2, imunossupressora, e óxido nítrico, indutor de morte de linfócitos por apoptose. No fígado ocorre também diminuição da produção de Inf- $\gamma$ pelos macrófagos.

- Células Dendríticas: após a fase inicial de ativação, por citocinas inflamatórias e produtos microbianos, passam a ter a capacidade de apresentação de antígenos diminuída, e, também são depletadas, por morte por apoptose, no baço, com forte repercussão na resposta imune. 
- Células NK: produzem inicialmente grandes níveis de Inf- $\gamma$, seguida de uma fase de diminuição da produção desta citocina.

Além de alterações nas funções das células de defesa, o componente humoral também fica intensamente ativado durante o quadro inflamatório, o que pode ser detrimental, ao se sobrepor a um quadro de resposta já desregulado. Assim, por exemplo, conforme observado em queimaduras extensas e em grandes traumas, ocorre uma superexpressão de receptores de complemento em neutrófilos, que pode resultar em excessiva quimiotaxia de polimorfonucleares, com maior recrutamento destas células em leito vascular pulmonar e desenvolvimento de edema de pulmão (Síndrome do Desconforto Respiratório Agudo).

A coagulação sangüínea se instabiliza na reação global ao trauma. Junto da liberação de proteínas de fase aguda, pelo fígado, que atuam no sentido de facilitar a imobilização de antígenos (ex.: proteína $\mathrm{C}$ reativa), outras forças têm papel importante nas hemopatias que acompanham o trauma severo. O aumento dos níveis de TNF- $\alpha$ circulante causa à expressão de fator tecidual na superfície de leucócitos e do endotélio. Esse fator é capaz de iniciar a cascata de coagulação, que, em condições normais, é controlada por anticoagulantes naturais, mantendo o efeito anticoagulante do fator tecidual, restrito ao sítio de injúria. Os fatores anticoagulantes envolvidos são: Proteína C ativada, antitrombina III, trombomodulina e glicopeptídeos heparina-símiles. Os anticoagulantes naturais podem atuar sobre as células do sistema imune e diminuir a inflamação. Por exemplo, a proteína $\mathrm{C}$ ativada diminui os níveis de interleucina- 6 e inibe a migração de neutrófilos. Produtos secundários à ação da trombomodulina inibem a ação do complemento $\mathrm{C} 5 \mathrm{a}$, que tem propriedades vasoativas, além de ser promotor da quimiotaxia, e, também induzir o mecanismo de morte por apoptose em linfócitos T. Nos quadros mais severos de sepse, os fatores anticoagulantes são consumidos devido à contínua ativação da coagulação, o que pode precipitar a coagulação intravascular disseminada com tromboses em microvasos, e hemorragias difusas, num quadro associado à falência de múltiplos órgãos e sistemas e morte (18).

O sistema imune celular específico é ativado, após a interação dos linfócitos $\mathrm{T}$ helper CD4, com as células apresentadoras de antígenos (macrófagos e células dendríticas maturas). Os linfócitos CD4 podem seguir duas vias de diferenciação, que resultam em 
fenótipo Th1 (T helper 1) ou no fenótipo Th2. As células Th1 produzem primariamente citocinas pró-inflamatórias (Inf- $\gamma$, IL-2) que também inibem o desenvolvimento das células Th2. As células Th2 produzem, primariamente, IL-4, IL-5, IL-6, IL-10, IL-13, que inibem o desenvolvimento de linfócitos Th1. Em condições normais, essas duas vias mantêm um delicado equilíbrio, permitindo a obtenção de resultados igualmente proporcionados no organismo. Porém, após uma injúria severa, devido ao meio rico em mediadores inflamatórios (a partir das células imunes inespecíficas, e mesmo de células Th1), a diferenciação dos linfócitos CD4 fica alterada, e, em 12 a 72 horas, estes diminuem sua produção de citocinas inflamatórias, surgindo uma predominância de interleucina 4, Th2 produzida.

Vários trabalhos confirmaram que o aumento das respostas do tipo Th2 pode proteger contra o excesso de inflamação. Contudo, outros observam que, na sepse, de fato, ocorre uma intensa e equilibrada supressão todos os fenótipos, sejam linfócitos Th1 ou Th2. Tais trabalhos concordam em que as funções dos linfócitos $\mathrm{T}$ ficam intensamente deprimidas, e, caso assim persistam, associam-se a um acentuado aumento da morbidade e mortalidade, a despeito de qualquer tipo de trauma, ou agente infeccioso (19).

A diminuição intensa do número de linfócitos totais (periféricos e centrais), o pleiotropismo das citocinas, e a queda dos níveis de citocinas inflamatórias em poucas horas após o trauma (de acordo com o perfil genético individual), são fenômenos que têm originado controvérsias, quanto ao valor orientador da monitoração dos níveis de fatores humorais, no tratamento da sepse. Apesar de tais relatos, é consenso, entre os pesquisadores, que algumas citocinas são imunodepressoras durante o processo inflamatório. Por exemplo, TGF- $\beta$, IL-10 e PGE2, são liberados, in vitro, por macrófagos que fagocitam os linfócitos em apoptose. Isso se conecta a constatação de que TGF- $\beta$ inibiu a capacidade de apresentação de antígenos, feita por macrófagos e células dendríticas (20).

A previsão de complicações no trauma e sepse constitui, efetivamente, um aspecto desafiante aos protocolos de tratamento. É comum, em unidades de terapia intensiva, a súbita mudança de quadro, em pacientes que apresentavam parâmetros adequados, tais como: bom fornecimento e consumo de oxigênio e de nutrientes, antibioticoterapia plena, ausência de germes patogênicos. Com esse aspecto desnorteante, algumas casuísticas ressaltam a ausência de correlação dos óbitos com as causas mais concebíveis de morte 
nesses pacientes (microtrombos, presença de microorganismos, ou sinais de necrose suficientes para afetar a função do órgão em falência) (21).

Assim, novas abordagens têm sido realizadas para o melhor entendimento das complicações da resposta inflamatória generalizada. Dentre as mais recentes, podemos encontrar a hipótese de que um "atordoarmento" metabólico, conseqüente à hipóxia inicial (ou devido a algum mediador químico, com níveis elevados durante a sepse) poderia levar a um desarranjo funcional de sistemas enzimáticos em diversos órgãos. Outras linhas tentam esclarecer o papel do endotélio no controle da coagulação na sepse (22). A constatação de altos níveis de DNA no sangue periférico de pacientes com trauma e sepse, levou à revisão dos conceitos de transferência de imunidade entre células por DNA extracelular feitos em 1980 e expandiu a pesquisa do trauma ao campo da epigenética $(\mathbf{2 3}, \mathbf{2 4})$.

Uma das maiores repercussões das técnicas de biologia molecular no tratamento experimental da sepse talvez decorra da intensa redução da mortalidade obtida em animais transgênicos,que superexpressam substâncias envolvidas no controle da inflamação e da sobrevivência celular, sem a associação de antibióticos. Sejam exemplos os tratamentos com anti-retrovirais (25), com fatores controladores da coagulação (26), ou com inibidores de receptores de complemento pró-apoptóticos em membrana (27), tais procedimentos sugerem o potencial terapêutico do manuseio molecular de tais mecanismos, evolutivamente conservados, de sobrevivência celular, no tratamento da sepse. Neste aspecto, é válido observar que, apesar das limitações da transposição de resultados com animais para os humanos, o modelo animal pode ajudar na obtenção de um melhor esclarecimento da patologia do trauma, especialmente se estiverem em foco mecanismos conservados entre as espécies (28).

\subsection{Imunodepressão e apoptose de linfócitos na sepse}

A linfopenia periférica dos quadros de trauma ou sepse acomete, sobretudo, os linfócitos CD4 e B. Embora relacionada ao seqüestro de linfócitos para os linfonodos regionais dos sítios inflamatórios, tem sido atribuída, principalmente, à morte celular pelo mecanismo de apoptose, observada em tecido linfóide. A principal causa da ativação das vias moleculares de apoptose na sepse, se deve à produção aumentada de corticosteróides, 
embora outros mecanismos, como o estresse oxidativo, o fator de necrose tumoral alfa circulante e o Complemento C5a também possam ser citados (29).

A influência do linfócito em apoptose sobre a evolução da sepse foi comprovada por Hotchkiss, que obteve aumento da mortalidade de camundongos sépticos ao injetar-lhes linfócitos apoptóticos de baço, enquanto a injeção de esplenócitos em necrose levou a um número menor de óbitos. A transferência de linfócitos normais, naquele modelo experimental, não ocasionou efeitos significativos. Em seus trabalhos, Hotchkiss lembra a possibilidade de que esse resultado poderia ser explicado pela ação de citocinas imunodepressoras, tais como IL-10 e TGF- $\beta$, liberadas pelos macrófagos que fagocitaram linfócitos em apoptose (30).

\subsection{Papel de proteínas do citoesqueleto e da matriz extracelular na sobrevivência celular.} durante a sepse

A integridade do citoesqueleto, composto principalmente por filamentos de actina, é fundamental para o controle de diversas funções celulares, tais como o transporte do citoplasma para o núcleo, de proteínas sinalizadoras, e migração celular (31). Os filamentos de actina têm, também, propriedades inibidoras sobre enzimas degradantes de DNA (32), e talvez se correlacionem ao processo energético celular, devido ao fato de se ligarem à fosfofrutoquinase envolvida no metabolismo da glicose (33). A ativação da enzima Caspase-3, durante a apoptose, leva à clivagem de actina, e contribui para a proteólise na perda de massa muscular em condições catabólicas, como uremia e diabetes (34). O aumento dos níveis de actina filamentosa no sangue periférico, durante a sepse, se correlaciona com o surgimento da síndrome de angústia respiratória (35). O extravasamento de actina pelas células lesadas surge em várias situações de estresse, principalmente na isquemia tecidual. Tal excesso causa intoxicação sistêmica, com agravamento da função renal, observadas em modelos experimentais (36).

A actina sofre, normalmente, um contínuo processo de formação-desintegração, sob o controle de ATP, que envolve a agregação de monômeros de actina globular, em polímeros de actina filamentar. As proteínas que se ligam aos monômeros de actina, impedindo a formação do filamento, são, portanto, ditas proteínas sequestrantes da actina $\mathrm{G}$ 
(globular, monomérica), que, agrupadas em 150 tipos, têm como as mais atuantes: Timosina, cofilina, gelsolina e profilina (37).

Timosina B4 é um peptídeo de 46 aminoácidos (Massa molecular 5,0 Kilodaltons Ponto isoelétrico 4,9), originado da fração 5 das timoglobulinas do extrato tímico, obtido por extração com tripsina e etapas de centrifugação, em acetona/álcool) (38). Tb4 é também encontrada em exudatos inflamatórios e retarda a migração de granulócitos, sendo, porém, necessária aos processo de cicatrização (39). Tal inibição contrasta com seu efeito promotor da proliferação de linfócitos a estímulos mitogênicos (40).

As proteínas de sustentação da matriz extracelular ( fibronectina e laminina) e as do citoesqueleto (actina) fazem ligação entre si, tanto anatômica como funcional ,através das proteínas integrinas, que atravessam a membrana plasmática. O recrutamento e ativação de quinases citoplasmáticas, agrupadas aos dímeros de integrina transmembrana plasmática, em conseqüência a fatores extras celulares (fatores de crescimento, fatores de sobrevivência celular) podem levar à ativação da enzima Akt-PKB, com influência sobre a viabilidade celular. Quando aplicada intraperitonealmente em camundongos com infarto agudo do miocárdio, Tb4 (atuante sobre a integridade dos filamentos de actina) foi capaz de ativar as quinases ligadas à integrina nas células do miocárdio, (associadas à ativação de Akt), com a obtenção de sobrevivência do tecido hipóxico, o aumento de $30 \%$ da força de contração cardíaca (41) e a relação direta com o aumento da expressão no miocárdio. Tal tratamento correlacionou-se ao não surgimento de insuficiência cadíaca, ausência de morte de miócitos, e maior contratilidade cadíaca; provocou também, o aumento da expressão desta enzima em interstício pulmonar $(\mathbf{4 2}, \mathbf{4 3})$.

A diminuição da concentração de fibronectina no sangue periférico é um fator discriminativo de mortalidade na sepse (44) e trauma (45). O surgimento de polímeros de actina e fibronectina foi inclusive encontrado em gatos com nefrite tubulointersticial (possível complicação da sepse) (46). Esses polímeros são formados por ação da enzima transglutaminase tecidual.

A TG cataliza a formação de ligações covalentes de glutamil-lisina entre resíduos peptídicos de glutamina e os grupos lisina de várias aminas, e possui como substratos várias proteínas da matriz extracelular, causando a estabilização da fibrina por sua ligação com fibronectina, daí sua outra denominação como Fator de coagulação XIIIa ou fibrinoligase 
(47). TG age em muitos processos intra e extracelulares importantes para a cicatrização, que incluem: apoptose, osteogênese e adesão celular. A expressão de TG é disseminada, e ocorre em várias doenças inflamatórias, tais como a Doença de Crohn, Doença Celíaca, Miosite de Corpos de Inclusão, e durante a resposta inflamatória sistêmica conseqüente à administração de lipopolissacarídeo (48), o que encontra vínculo com sua ativação, in vitro, partir de TNF $\alpha$, liberado por macrófagos (49). Apesar de ter sido considerada um agente estabilizador da inflamação (50), trabalhos posteriores mostraram o aumento da atividade de TG associado à ativação de fosfolipase A2, estimuladora da formação de prostaglandinas e leucotrienos, pró-inflamatórios. Neste sentido, por exemplo, foi relatada a menor intensidade dos sinais clínicos de inflamação, com o emprego de peptídeos simultaneamente bloqueadores de TG e fosfolipaseA2, em comparaçãon com o bloqueio exclusivo dessa fosfolipase (51).

\subsection{Reversão de Apoptose na Sepse e Substâncias de Sobrevivência Celular}

O mecanismo de morte por apoptose, inicialmente descrito como picnose, caracteriza-se por dissolução da cromatina em segmentos de DNA, lesão de proteínas do citoesqueleto, encolhimento celular, irregularidades em membrana ("blebbing”) e ausência de extravasamento de enzimas para o meio extracelular, o que leva à mínima reação inflamatória local, sem repercussão significativa no ambiente de sustentação da célula. Tal lesão decorre da digestão de proteínas do citoesqueleto, e do DNA celular pelas Cisteíno Aspartato Transferases (caspases) citoplasmáticas.

A estabilização da membrana mitocondrial impede a ativação do processo de morte linfocitária por apoptose. A presença da proteína BCL-2, ancorada na membrana interna da mitocôndria, lhe confere maior resistência aos estresses eletroquímicos vigentes no citoplasma, exacerbados durante o choque, trauma e sepse. O aumento da expressão de tais proteínas estabilizadoras é capaz de impedir o mecanismo de apoptose na sepse. Assim, por exemplo, a superexpressão de BCL-2 em linfócitos, em animais transgênicos, reduziu a mortalidade na sepse induzida por punção cecal (52). BCL-2 apresenta conexões moleculares com outras vias envolvidas na manutenção do equilíbrio energético celular, que podem ser ativadas pelas chamadas Substâncias de Sobrevivência Celular, presentes no 
meio extracelular. A atuação dessas substâncias sobre o complexo Fosfatidil Inositol 3fosfato (PI3-K), na face citoplasmática de membrana, mobiliza as enzimas Akt / ERK, que formam uma seqüência atuante em diversas funções da celula, tais como sobrevivência, proliferação e diferenciação (figura 1). A ativação dessas quinases dependentes de inositol trifosfato (Akt) é uma etapa comum na sinalização de fatores de crescimento relacionados à insulina, embora as seqüências de sinalização posteriores possam divergir, na dependência do contexto celular e da presença de estímulos pró-apoptóticos.

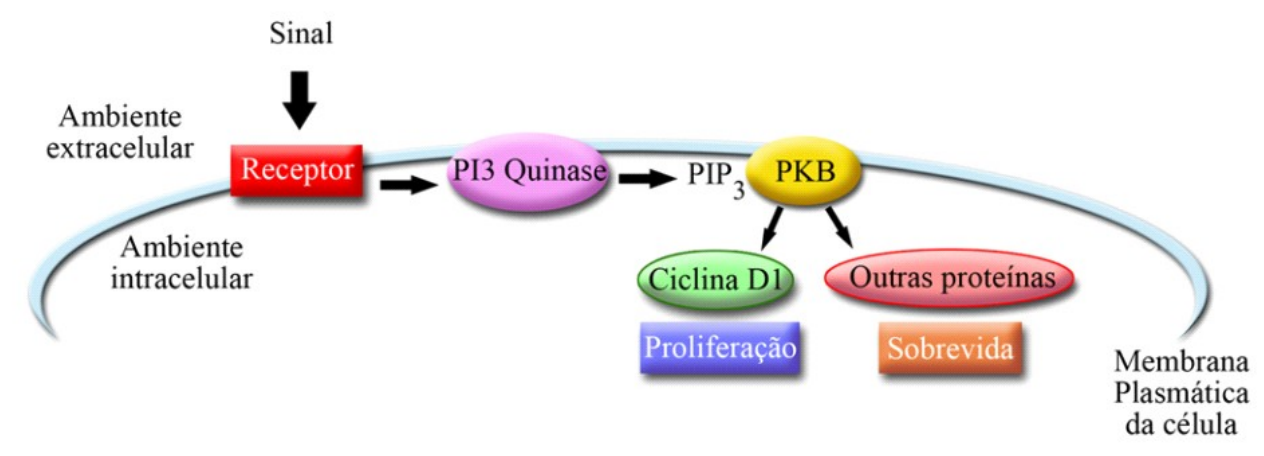

\section{Figura 1 - Apresentação esquemática demonstrando as vias de sinalização e funções relacionadas com a enzima Akt-PKB}

Os diversos receptores de fatores de crescimento associados à insulina, possuem várias estruturas. A união do ligante (fator de crescimento) a esses receptores resulta em autofosforilação de resíduos de tirosina na molécula do receptor e posterior fosforilação de outras proteínas intracelulares, entre as quais a quinase dependente de PI3-K que levam à ativação de fatores de transcrição, e à ativação da proteína-quinase $\mathrm{B}$ ( ou Akt), e proteinaquinases ativadas por mitógenos (ERK 1/2) estimuladoras da proliferação celular. Akt possui vários substratos, além de proteínas BCL-2 e fatores de transcrição, incluindo outras 
proteínas da família BCL-2, com funções pró-apoptóticas. A proteína Akt faz parte de uma via sinalizadora que promove tanto a proliferação (atuando sobre a proteína Ciclina D1), como a sobrevivência celular, inibindo a ativação de Caspase 9 e a formação do fator de transcrição da proteína FAS-L pró-apoptótica. Animais transgênicos, que superexpressam Akt, são mais resistentes a sepse e outros estímulos apoptóticos (53).

Fica, deste modo, possível entender o fundamento biológico pelo qual substâncias comprometidas com a manutenção de diversas funções celulares possam convergir funcionalmente para a expressão de fatores relacionados à sobrevivência celular, capazes de resgatar a célula do processo apoptótico. Tal grupo de substâncias inclui, no sistema imune: IL-2, IL-7, Timosina-B4, Insulina, Hormônio do Crescimento, Prolactina (54). Dentre estas, IL-7 é produzida em abundância pelo timo de recém-natos, sendo fundamental para a diferenciação e maturação de linfócitos T (55).

Vários experimentos estabeleceram que a prevenção da morte de linfócitos aumenta a sobrevida na sepse. Por exemplo, anti-retrovirais (inibidores da enzima transcriptase reversa) empregados no tratamento da Síndrome de Imunodeficiência Adquirida mostraram efeito positivo em animais sépticos, sugerindo uma atuação sobre a integridade de proteínas controladoras do fluxo iônico da membrana mitocondrial (25), ou, ao inibir a degradação, pelos proteosomas, de fatores de transcrição relacionados à sobrevivência celular. Bloqueadores de receptores de corticóides e inibidores de caspases também apresentaram efeito positivo na sobrevivência da sepse em animais. Contudo, a necessidade do papel metabólico compensador dos corticóides, durante a sepse, e os efeitos tóxicos dos inibidores de caspases, impedem seu uso como agentes terapêuticos $\mathbf{( 5 6 , 5 7 ) . ~}$

\subsection{Experiência Clínica com Hormônios Tímicos}

$\mathrm{Na}$ década de 60, experimentos com camundongos timectomizados mostraram, uma melhora na imunidade celular, e cura de emagrecimento e diarréia associados (wasting disease), após o implante de timo íntegro, em câmaras de teflon, o que sugeriu a elaboração

de fatores hormonais $(\mathbf{5 8}, \mathbf{5 9})$. Posteriormente, o implante de epitélio tímico, levou à maturação de linfócitos em camundongos BalbC (nude) caracterizados pela deficiência congênita do desenvolvimento do timo. A administração de hormônios tímicos, em BalbC, 
contudo, mostrou resultados controversos (60).

Na hipótese de que esses hormônios pudessem reverter algumas imunodeficiências, foram realizadas algumas tentativas de correção em humanos. Transplantes de timo em Síndrome de Imunodeficiência Combinada, patologia caracterizada por defeitos enzimáticos intracelulares, foram realizados na década de 70 , em pacientes que não puderam realizar transplante de medula óssea. Em 30 pacientes que receberam tal tratamento, 27 apresentaram melhora do tempo de sobrevida e do quadro clínico. No entanto, 3 casos desenvolveram linfoma. Pelo acidente ocorrido, chamou-se a atenção para a possibilidade de que fatores liberados pelo timo poderiam atuar no controle da proliferação e diferenciação linfocitárias (61).

Timosina alfa-1, ao lado de outro peptídeo tímico, Timopentina, tem sido usada, na Europa, como adjuvante em imunodepressões, com relatos de efeitos positivos em infecções em idosos (62). Foi relatado que uma outra fração das timosinas, Timosina alfa1, impediu, in vitro, a apoptose de linfócitos $\mathrm{T}$, induzida por glucocorticóide (dexametasona) (63), bem como diminuiu a mortalidade de ratos com choque séptico obtido por aplicação de lipolissacáride intraperitoneal (64). No presente momento, Timosina B4 está sendo submetida em Fase II de um estudo como estimulante da cicatrização pós-vitrectomia em diabéticos, e, em outro estudo, na Fase I no Infarto Agudo do Miocárdio, ambos nos EUA (65).

Na Duke University, um pequeno grupo de crianças com agenesia tímica congênita (Síndrome de DiGeorge), obteve uma melhora significativa na qualidade e no tempo de sobrevida, após o transplante de segmentos de timo de humanos recém-natos, em um estudo iniciado em 1996. A maior parte dos óbitos foi conseqüente de distúrbios não imunológicos da doença (66). Dessa forma, foi comprovada a existência de um efeito recuperador da imunidade causado pelo tratamento com tecido tímico exógeno, em humanos com imunodeficiência congênita.

\subsection{Hipótese de trabalho}

A maior suscetibilidade à infecção nos pacientes acometidos por sepse acompanha a falha do sistema imune, que fica evidente em 12 a 24 horas após o evento agressor (12), e 
está correlacionada com a intensa apoptose de linfócitos (21), o extravasamento de actina celular para o interstício da musculatura esquelética (34) e a diminuição dos níveis de fibronectina do plasma (45). A diminuição da apoptose linfóide e conseqüente aumento da sobrevivência do organismo podem ser obtidos na sepse através da superexpressão de algumas proteínas intracelulares (53), ou pela ação de fatores presentes no meio extracelular, atuantes na manutenção da integridade de membranas e do citoesqueleto. Diversos desses fatores são secretados pelo timo, sobretudo no animal recém-nato. Como exemplos, encontram-se as interleucinas 7 e 15 (55), e o hormônio Timosina B4, que é capaz de ativar quinases ligadas à integrina transmembrana, e impedir a morte de células miocárdicas frente à agressão isquêmica (41), e também, de reduzir a inflamação sistêmica e mortalidade no modelo de sepse induzida por lipopolissacáride (63).

Não obstante os surgimentos de polímeros de actina e fibronectina estarem relacionados à morte celular, existe poucas referências, disponíveis na literatura, quanto a estudos imunohistoquímicos dessas moleculas no timo, durante a sepse. Em vista da possibilidade de substâncias promotoras da sobrevivência celular estarem presentes no sobrenadante de cultura de timo de recém-nato, procurou-se observar, neste trabalho, as expressões simultâneas de fibronectina e actina, nos timos de ratos Wistar adultos com sepse, pelo modelo de ligadura e punção cecal, tratados com o sobrenadante de cultura de timo de ratos Wistar neonatos, saudáveis. A aglomeração de fibronectina intersticial, junto a actina extravasada pelas células lesadas, deve-se a enzima transglutaminase tecidual, que pode ser ativada tanto na apoptose como durante o processo inflamatório .Por isso, buscou-se um melhor discernimento entre a possibilidade de ação anti-inflamatória do sobrenadante, e efeitos compatíveis com a estimulação de mecanimos de sobrevivência celular (Figura 2) . Para essa finalidade avaliou-se o resultado do tratamento com sobrenadante de cultura de timo de animal recém-nato sadio, sobre a clínica da inflamação isolada de musculatura de pata, por injeção intramuscular de glutaraldeído, em animais sem sepse. Também foi observado o efeito sobre a mortalidade no rato Wistar adulto com sepse, submetido ao mesmo tipo de tratamento. Tais observações podem auxiliar os estudos experimentais de sepse. 


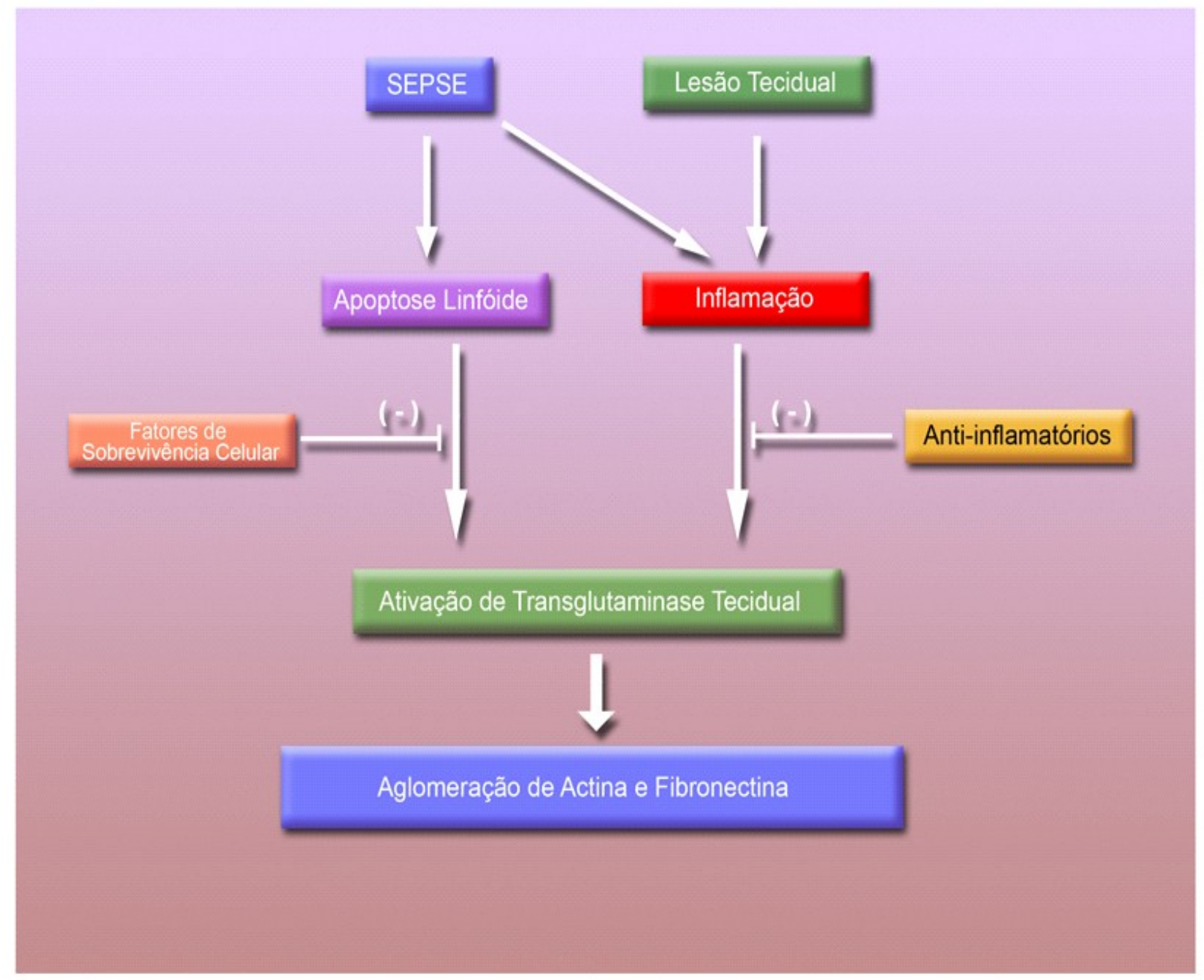

Figura 2 - Apresentação esquemática mostrando que substancias sem efeitos antiinflamatórios bloqueiam aglomeração de actina devido a ação sobre mecanismos de sobrevivência celular. 


\subsection{Objetivos:}

Observar os efeitos sobre a mortalidade e a evolução clínica, de ratos Wistar adultos com sepse por ligadura cecal com punção, causados pelo tratamento com sobrenadante de cultivo do explante de timo de ratos Wistar recém-natos saudáveis.

Observar o efeito sobre a intensidade de expressão de actina e fibronectina intersticiais nos timos de de ratos Wistar adultos com sepse por ligadura cecal com punção, causados pelo tratamento com sobrenadante de cultivo do explante de timo de ratos Wistar recém-natos saudáveis.

\section{MATERIAIS E MÉTODOS}

- Grupos: O estudo de mortalidade envolveu três grupos com 20 animais cada (tratados com meio de cultura apenas; tratados com sobrenadante; punção cecal apenas). $\mathrm{O}$ estudo imunohistoqímico foi realizado 24 horas após a punção cecal, e usou quatro grupos com cinco animais (sem qualquer procedimento; punção cecal apenas; punção tratada com sobrenadante; punção tratada com meio apenas). Para a observação de inflamação de pata foram usados 02 grupos com 10 animais (punção cecal tratada com sobrenadante, e, punção cecal tratada com meio apenas).

- Análise de dados: Foram observados mortalidade e sinais clínicos até o quinto dia póspunção cecal. Os sinais clínicos foram enquadrados como de doença (piloereção, edema de pálpebras, dificuldade respiratória), ou comportamento doentio (marcha lentificada, apatia, falta de comportamento exploratório). Os sinais básicos de inflamação (edema, vermelhidão, calor e perda da função) em pata foram monitorados até o quinto dia pósinjeção de glutaraldeído. As lâminas para análise da expressão de actina e fibronectina, com 24 horas após a punção cecal, foram examinadas por um patologista, sendo consideradas três possibilidades: expressão normal, expressão diminuída e expressão aumentada. Cada animal originou dez lâminas para estudo: cinco para actina e cinco para fibronectina. A probabilidade de sobrevida acumulada foi estimada a partir do método de Kaplan-Meier e a comparação das curvas foi feita por meio do teste do log-rank. Comparações múltiplas entre as curvas de sobrevivência foram feitas controlando-se o erro tipo 1 pelo método de Bonferroni. Ajustou-se o modelo de Cox para a verificação de diferenças entre grupos e 
para obter-se uma estmativa paraosriscos desejaveis.

Teste e análises gráficas foramrealizadas para a adequação do modelo de Cox. A análise da presença de fibronectina foi feita pelo teste de associação pelo qui-quadrado, ou pelo teste exato de Fischer. Em todas as análises o resultado foi considerado estatisticamente significativo quando $\mathrm{p}<0,05$. A análise estatística foi feita utilizando o pacote estatístico SPSS para Windows (versão 12.0) (Microsoft Co USA).

- Animais: Os procedimentos foram aprovados pela Comissão de Ética para Experimentação com Animais do Instituto de Ciências Biomédicas da Universidade de São Paulo. Foram empregados ratos Wistar, não isogênicos, fêmeas $(150$ - 250g), aclimatizados e mantidos em gaiolas individuais, sob condições constantes de temperatura (22-25 graus C), umidade (50\%), ciclos de iluminação de 12/12 horas, alimentados com ração balanceada padrão (NUVILAB-CR1, Nuvital SA, Paraná Brasil, lote: 2908001) e ingestão de água filtrada de torneira, ad libitum. Todos os animais foram sacrificados ou mortos até o quinto dia após punção, com doses de Ketamina cinco vezes superiores à dose anestésica. Amostras de fezes, jejuno, ceco e intestino grosso, e de orofaringe, de animais adultos, cultivadas pelo sistema EnteroKit B (PROBAC) e bioMérieux (França), mostraram: Citrobacter rodentium, Klebsiella pneumoniae, Proteus mirabillis, E.coli, Enterobacter aerogenes, Serratia marscecens, Serratia odorifera, Staphylococcus sp.

- Ligadura cecal com punção: O procedimento adotado segue o padrão preconizado originalmente por Witcherman (67), preferido por ser um modelo clínico de sepse, internacionalmente validado, que evita variações individuais, refentes ao tempo e intensidade de resposta, comuns em outros modelos (28). Após injeção peritoneal de solução de Cloridrato de Ketamina 60 mg/Kg (KETAMIN-S(+), Crisália SP, Brasil, lote 040523994) e Cloridrato de Tiazina a 2\%, 0,05 mg/Kg (ROMPUM, Bayer, SP, Brasil, lote 002-03), é feita uma incisão em linha mediana do músculo reto abdominal e o ceco é exposto, com o seu conteúdo ordenhado no sentido distal. É feita uma ligadura com fio seda 3-0 (logo abaixo da válvula íleo-cecal, de modo a manter o trânsito intestinal. 
Punciona-se uma vez a face antemesentérica do ceco com agulha de calibre $18 \mathrm{G}$ para ratos, e $25 \mathrm{G}$ para camundongos. O ceco é recolocado na cavidade abdominal, que é fechada em dois planos (músculo e pele), com fio mononylon 3-0. Logo após o fechamento da cavidade, injeta-se $1 \mathrm{ml}$ de solução salina físiológica subcutaneamente em dorso, a fim de evitar colapso circulatório decorrente do edema intestinal. Não foram utilizados antibióticos em doses terapêuticas ou profiláticas para o animal. Como analgésico pós-punção, foi empregado Cloridrato de Tramadol (TRAMAL ampolas 50mg/ml, Pharmacia \& Upjohn, São Paulo, Brasil, lote 03062006) na dose de $2 \mathrm{mg} / \mathrm{Kg} /$ dia ,aplicado via subcutânea por 3 dias.

- Inflamação muscular por glutaraldeído: Após anestesia citada os animais tiveram o trem posterior tricotomizado, sendo então injetado 0,1 microlitro de solução de glutaraldeído a 2\% em musculatura de pata. Em seguida, foram acompanhados como no pós-operário dos animais submetidos à punção cecal..

- Culturas de timo: Em área estéril por chama, os animais recém-natos são anestesiados por imersão em gelo por um minuto, colocados sobre bandeja de dissecção e imobilizados com fita adesiva. Passa-se álcool anidro hidratado a $70 \%$ (lote 98-05/2005, Cia. Nacional de Álcool, São Paulo, Brasil) sobre a pele de todo o corpo, exceto crânio. É feito um corte, longitudinal, mediano, de $0,5 \mathrm{~cm}$ com tesoura em tórax. Utilizando-se pinças para cirurgia vascular, remove-se o timo, que é colocado em meio DMEM em temperatura ambiente, e levado para câmara de fluxo, para preparo. O timo é cuidadosamente colocado em uma outra placa de Petri, fatiado com bisturi, e posto em poço de placa de cultura de poliestireno, com 48 poços (Nunclon Surface, lote 070121 - Nunc A/S, Roskilde Dinamarca,) junto com 3,0 $\mathrm{ml}$ do meio de cultura para cada timo, onde permanece por 48 horas em estufa de atmosfera a 37 graus centígrados, com $\mathrm{CO}_{2}$ a $10 \%$. O grau de viabilidade foi feito pela constatação de: confluência celular atingindo 80-100\% da área do fundo do poço de cultura, ausência de bolhas intracelulares, ausência de colônias de microorganismos, manutenção da cor do meio, e tomado em fotografia, com aumentos de 20 e 40 vezes, em microscópio invertido (NIKON ECLIPSE TE-200, Nikon Co, Japão). Como meio de cultura empregou-se a Solução de Meio Eagle Dulbecco Modificado (DMEM, Dulbecco Modified Eagle Medium, BioWhitaker, Lot 01105331, Cambrex- 
Bioscience Walkensville, Inc USA), com 4,5 g/L de glicose sem soro, suplementado com as seguintes substâncias (para cada $100 \mathrm{ml}$ de DMEM): 1,0 ml (2 mM) de L-glutamina (Lglutamine, lot 1291801, Invitrogen USA), 1,0 $\mathrm{ml}(0,1 \mathrm{nM})$ de aminoácidos não essenciais (MEM Non-Esstential Aminoacids Solution, lot 1316287, Gibco-Invitrogen, Grand Island, USA), 1,0 $\mathrm{ml}(0,1 \mathrm{mM})$ de vitaminas (MEM Essential Vitamins Mixture, lot 1316287, Gibco-Invitrogen Grand Island USA),1,0 ml de piruvato de sódio (1nM) (Hy Q, Hyclone, USA, lot 17NM 201 138), 100 microlitros de 2 mercapto-etanol, (10 a -5 mM) (SIGMA, lot 119H09142, Sigma Chemical Co, St Louis, USA) 1ml de piruvato de sódio (1mM) (Hy QSoidium Pyruvate 100 nM, Hyclone, lot HNM 201138, Hyclone USA), 500 microlitros de gentamicina (Gentamicin Solution, $10 \mathrm{mg} / \mathrm{ml}$, lot 1027177, Gibco, Grand Island, USA).

$\mathrm{O}$ pH ficou ajustado em 7,3.

- Tratamento com sobrenadante de cultura: O sobrenadante de cultura, ou de meio DMEM suplementado sem soro, após 36-48h de cultivo, é retirado, passado em filtro de 0,22 micra (Filtropur SO.2 lot 020200, Sarstedt Aktiengenlllshaft, Nümbrecht, Germany), e aplicado 1,0 ml, por injeção intraperitoneal, entre uma e duas horas após ligadura cecal, ou após a injeção de glutaraldeído. Cada animal recebeu o sobrenadante de um timo exclusivamente.

- Imuno-histoquímica: A reação imuno-histoquímica $(68,69)$ foi realizada no laboratório de imunohistoquímica da Divisão de Patologia do Instituto Adolfo Lutz -SP. O método foi empregado em fragmentos de timo fixados em formalina a 10\% e incluídos em parafina, nos quais foram realizados cortes histológicos com $4 \mu \mathrm{m}$ de espessura e montados em lâminas cobertas com 3-aminopropil-triethoxisilano (SIGMA-Aldrich Co. St Louis, USA), desparafinados e hidratados por meio de xilóis e alcoóis. Foi utilizado, na recuperação dos sítios antigênicos, tampão ácido cítrico $\mathrm{pH}$ 6,0 em panela de pressão por 3 minutos e 30 segundos,depois as lâminas foram lavadas em água corrente por 10 minutos. A atividade da peroxidase endógena foi bloqueada por imersão em peróxido de hidrogênio e metanol (vol/vol) (MERCK S.A. Indústrias Químicas, Rio de Janeiro), com 3 vezes, 5 minutos cada troca, em seguida as lâminas foram lavadas em água corrente por 10 minutos e os tecidos foram imersos em PBS pH 7,4 (tampão fosfato-Merck S.A. Indústrias Químicas, Rio de 
Janeiro), com 3 vezes, 5 minutos cada troca. Os anticorpos monoclonais primários nas titulações padronizadas para o CD3 1:400, CD20 1:1000, actina 1A4 1:4000 e Fibronectina 1:4000 (todos da DAKOPATTTS A/S Dinamarca) foram diluídos em BSA 1\% (em Solução Tampão de fosfato $\mathrm{pH}$ 7,4 e azida sódica 0,1\% (SIGMA-Aldrich Co. St Louis, Estados Unidos). Os cortes foram incubados com os anticorpos primários em câmara úmida por um período de 16 a 18 horas sob refrigeração (2-8 graus centígrados). A seguir os tecidos foram lavados e incubados com anticorpo secundário biotinilado (Kit LSAB, DAKO CYtomation) (Guesdon et al., 1979) em câmara úmida a $37{ }^{\circ} \mathrm{C}$ por 30 minutos. Seguiram-se novas lavagens com PBS, pH 7,4 por 3 vezes, 5 minutos cada troca. Em seguida procedeu-se a etapa da revelação com substrato cromogênico 3"3 diaminobenzida tetrahidrocloreto SIGMA-Aldrich Co, St Louis, USA) $1 \mathrm{mg} / \mathrm{ml} \mathrm{com} \mathrm{0,1 \%} \mathrm{(vol/vol)} \mathrm{de}$ peróxido de hidrogênio (Merck S.A. Indústrias Químicas, Rio de Janeiro, RJ) em tampão PBS pH 7,4 com a imersão dos cortes por 1 minuto. Em seguida, as lâminas foram lavadas em água corrente por 10 minutos e por 1 minuto em água destilada.Os cortes foram contracorados com hematoxilina de Harris, desidratados e, em seguida, procedeu-se a montagem das lâminas com meio de montagem (Entellan neu, Merck KGaA-Alemanha). Foram utilizados como controle positivo na reação imunohistoquímica cortes histológicos conhecidos. 


\section{RESULTADOS}

A possibilidade da presença de mediadores da proliferação e sobrevivência, no meio, foi comprovada pelo aspecto das culturas, que, após 36 horas, apresentaram boa resposta à técnica e aos materiais empregados. Não foram encontrados vacúolos, debris intracitoplasmáticos, ou variação da cor do meio. Além da disseminação por todo o poço de cultura, foi possível constatar a existência de aglomerados de células, evidenciando a função de proliferação, compatível com a viabilidade celular (Figuras 3 e 4).

Os timos dos animais tratados com cultivo sobrenadante mostraram menor intensidade de expressão de actina e de fibronectina (Figuras 5 e 6). Os animais com sepse não tratados e os tratados com meio de cultura apenas apresentaram maior expressão, com $\mathrm{p}$ (TESTE DE FISCHER): $<0.008$.

A análise de sobrevida incluiu dados do modelo original de sepse, proposto por Wichterman e de grupo controle atual, com sepse não tratada. Houve diferença significativa entre as probabilidades de sobrevida entre os quatro grupos, com p (log-rank): 0,0037. A maior sobrevida ocorreu no grupo tratado com sobrenadante, que mostrou $55 \%$ de probabilidade de sobrevida acumulada, contatada cinco dias após a punção cecal. Já no grupo tratado com meio apenas, esta probabilidade foi de $30 \%$ no $5^{\circ}$ dia (Figura 7 e Tabela 1). As piores taxas de sobrevida ocorrem nos grupos com sepse apenas e no modelo de Wichterman, os quais apresentaram pouca diferença entre si. Todos os animais tratados com sobrenadante ou meio de cultura apresentaram exclusivamente comportamento doentio (apatia, lentificação de marcha, perda do comportamento exploratório), sem sinais de doença (sangramento de mucosas, edema de pálpebra, tremores), enquanto todos os animais sépticos não tratados apresentaram comportamento doentio e sinais de doença.. A comparação múltipla entre as curvas de sobrevivência não mostrou diferença significativa entre o tratamento com sobrenadante e o tratamento com meio apenas. É válido observar, contudo, a menor inclinação na curva de sobrevida referente ao tratamento com sobrenadante.

Não foi detectado qualquer efeito clínico sobre a inflamação decorrente da injeção intramuscular de 0,1 microlitro de glutaldeído a $2 \%$, em patas de ratos Wistar saudáveis, e tratados com a aplicação intraperitoneal com sobrenadante de cultivo de timo de animal recém-nato. 


\section{DISCUSSÃO}

Não houve diferença estatisticamente significativa, no tocante a probabilidade acumulada de sobrevida entre o grupo tratado com sobrenadante e o grupo tratado com meio de cultura apenas.

Não obstante a pouca diferença, com relação à sobrevida pelo tratamento com meio apenas, observou-se que o sobrenadante de explante de timo foi, também, capaz de promover a sobrevivência e, de maneira única, reduzir a expressão de actina e fibronectina no timo do animal séptico, o que é compatível com a recuperação da integridade celular e tecidual. Estudos de identificação das substâncias presentes no sobrenadante, relacionadas com tal efeito, devem ser realizados visando maior esclarecimento.

A polimerização de actina e fibronectina na sepse é feita pela enzima transglutaminase tecidual, também implicada no controle da inflamação. A inibição da enzima transglutaminase é capaz de inibir o processo inflamatório. Dessa forma, a ausência de efeito sobre a evolução clínica da inflamação decorrente da injeção intramuscular de glutaldeído, sugere a prevalência da apoptose linfóide sobre

a polimerização de actina e fibronectina intersticiais.

Estes resultados sugeriram, ao autor, a efetiva estimulação dos mecanismos de sobrevivência celular em timo, e a ausência de efeito anti-inflamatório periférico, pelo tratamento com sobrenadante. Situação análoga pode ser vista em pacientes de trauma, tratados com insulina, os quais têm maior chance de sobrevida e menor intensidade de resposta inflamatória sistêmica, não obstante a conhecida ausência de efeitos antiinflamatórios diretos pela insulina (70).

Tais achados guardam semelhança com o tratamento realizado com $\mathrm{Tb} 4 \mathrm{em}$ camundongos com infarto do miocárdio, que apresentaram melhora da função cardíaca e diminuição da área de necrose miocárdica, porém sem efeitos sobre a mortalidade (41). Neste aspecto, os resultados de presente experimento ressaltam a capacidade de recuperação de função celular, além das conhecidas ações dos fatores de crescimento (proliferação, crescimento e sobrevivência).

Devido a tais conclusões, o autor sugere que o efeito de substâncias promotoras da sobrevivência celular produzidas pelo timo, no tratamento da sepse, deve ser mais 
estudado, e que, o exame imunohistoquímico simultâneo de actina e fibronectina nos tecidos sensíveis à morte por apoptose (ex.: timo, linfonodos), pode ser um método auxiliar para a elucidação dos resultados obtidos em tratamentos experimentais da sepse.

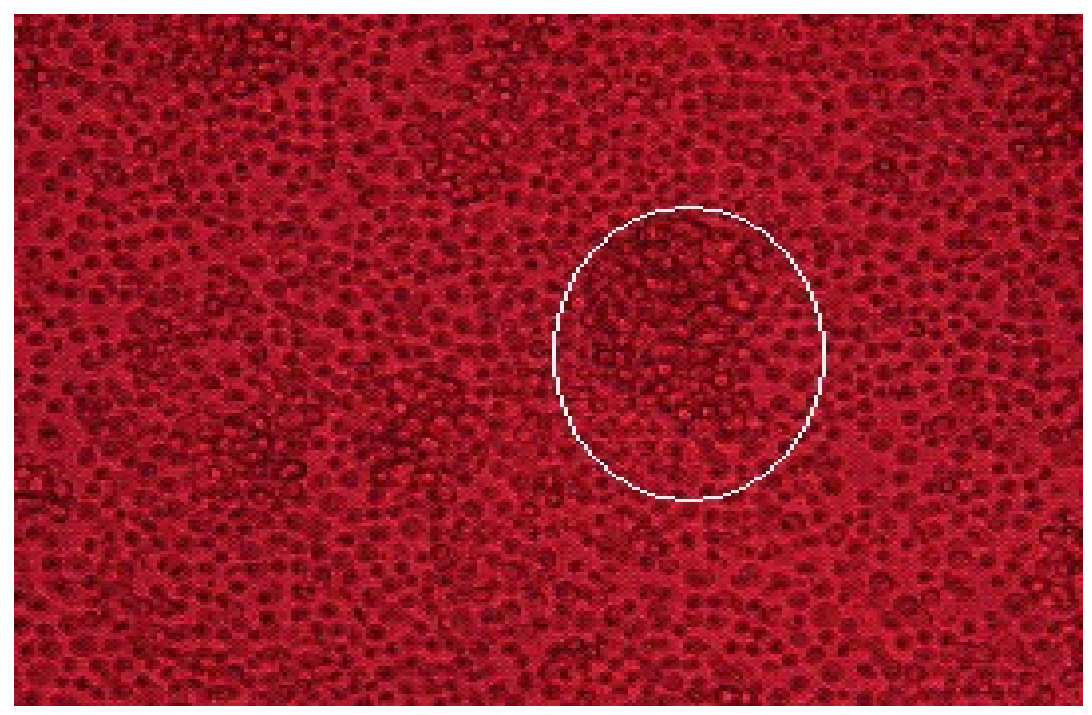

Figura 3- Cultura de explante de timo de rato Wistar recém-nato,após 24 horas de cultivo, em microscópio de inversão, com aumento de 40 vezes. A área demarcada mostra um aglomerado de células. 


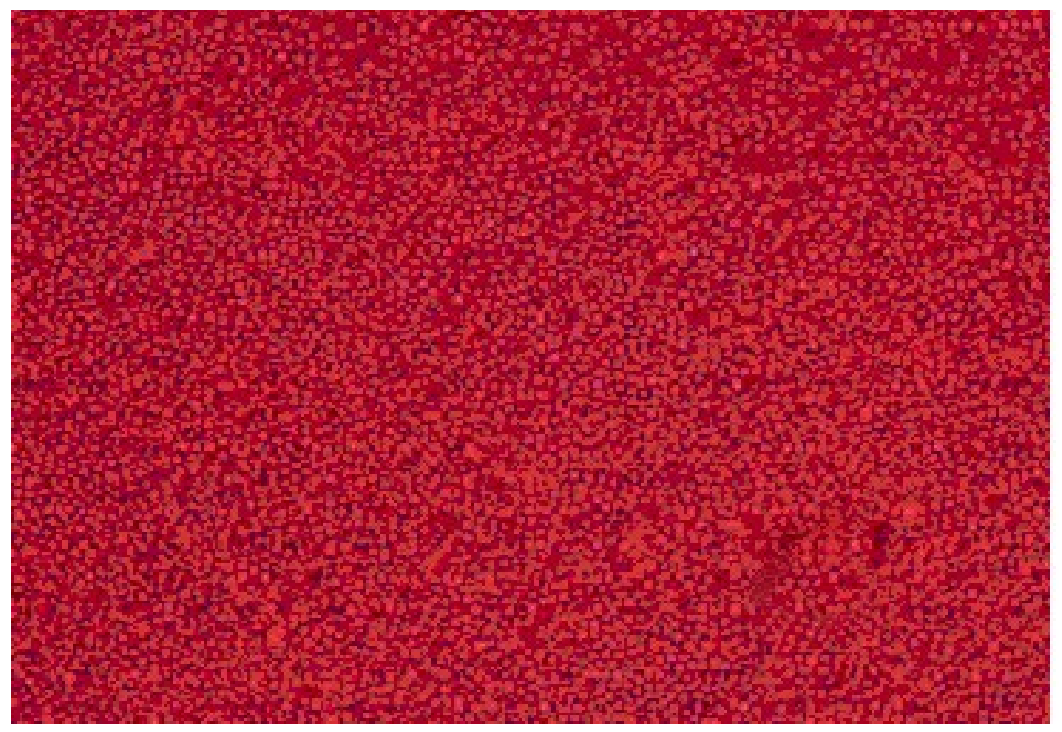

Figura 4- Cultura de explante de timo de rato wistar recém-nato, após 48 horas de cultivo, em microscópio de inversão, com aumento de 40 vêzes. Pode se observar a maior confluência da cultura, em relação à mostrada pela figura 3. 
NORMAL
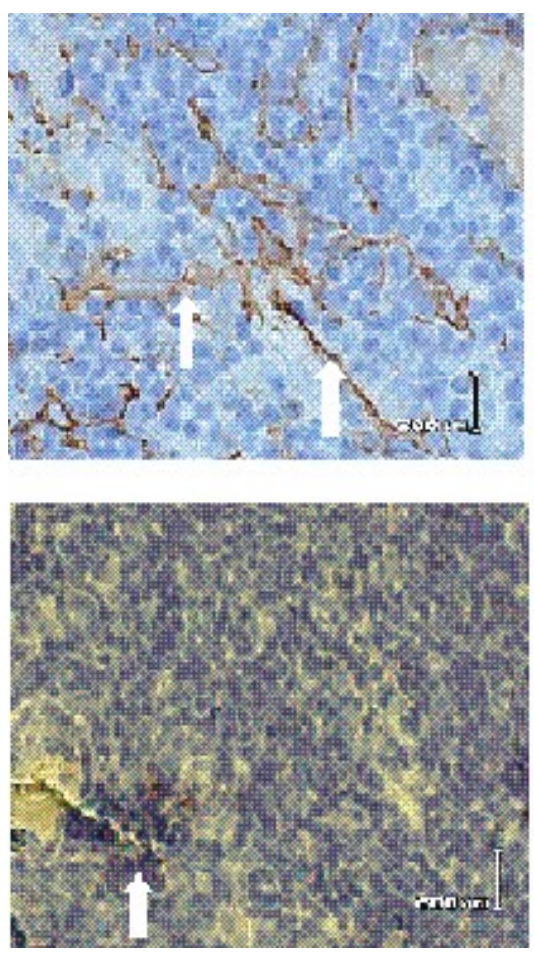

SEPSE APENAS
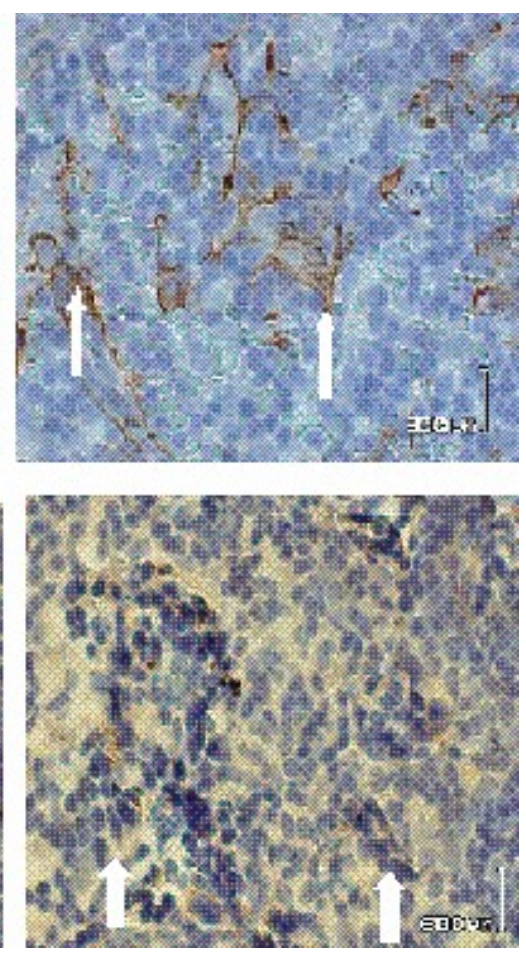

SOBRENADANTE

MEIO APENAS

Figura 5- Expressão de actina (aumento 400x). As setas brancas mostram feixes em marrom, correspondentes a áreas de expressão de actina. $O$ tecido que não apresentou reação imunohistoquímica para actina, foi corado com hematoxilina-eosina. 


\section{SEPSE APENAS}
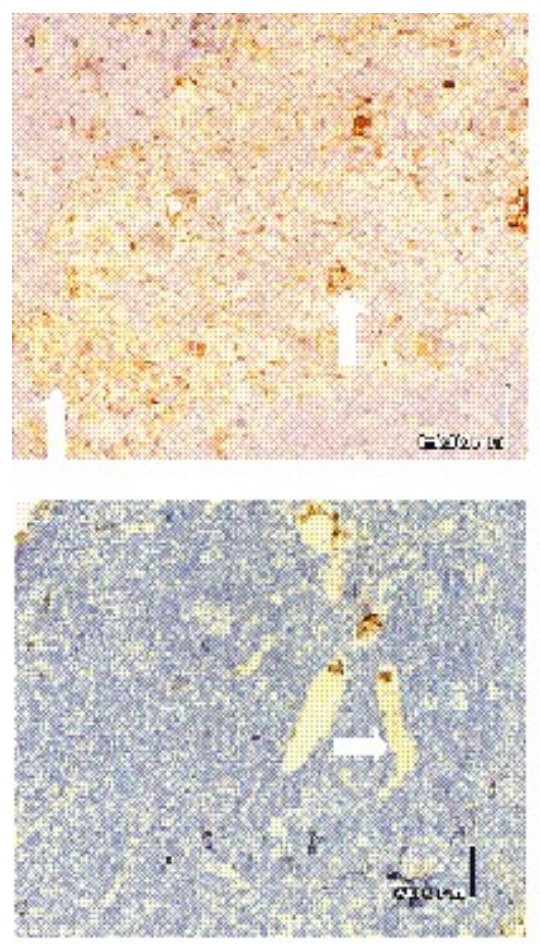

NORMAL
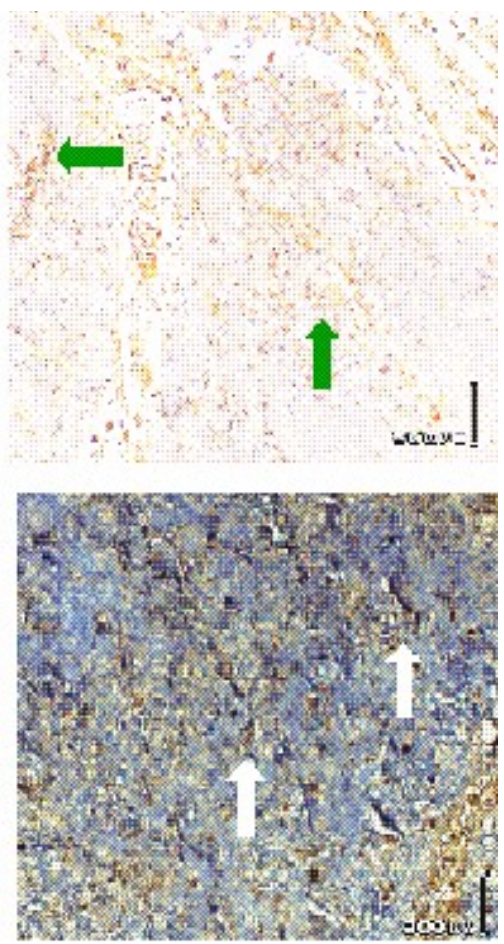

\section{SOBRENADANTE}

Figura 6- Expressão de fibronectina (aumento 100x). As setas indicam pontos marrons correspondentes a áreas de expressão de fibronectina. (No grupo "sobrenadante", a seta mostra fibronectina associada à parede de um vaso sangüíneo). $O$ tecido que não apresentou reação imunohistoquímica para actina, foi corado com hematoxilina-eosina. 


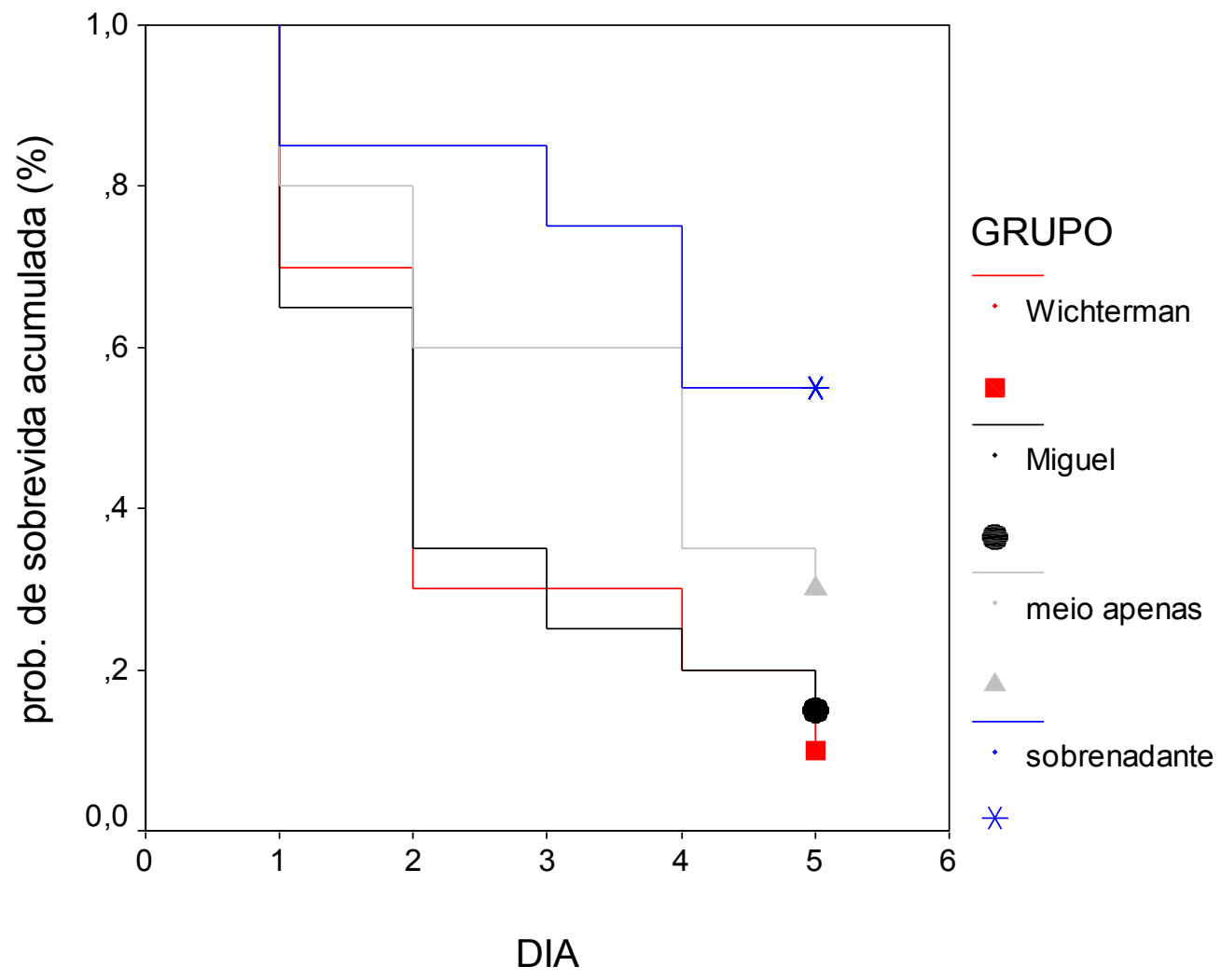

Figura 7- Gráfico mostrando o percentual de probabilidade de sobrevivencia em ratos Wistar acumulada até o quinto dia após ligadura e punção cecal l, com os tratamentos realizados neste estudo. As linhas "Wichterman" e "Miguel" referem-se a controles com sepse apenas, realizados no modelo original, e pelo autor da dissertação, respectivamente). 
Tabela 1 : Probabilidade de Sobrevida Acumulada Segundo Grupo (\%).

\begin{tabular}{lccccc}
\hline \hline & DIA & & & & \\
\hline \multicolumn{1}{c}{ GRUPO } & 1 & 2 & 3 & 4 & 5 \\
\hline Witcherman & 70 & 30 & 30 & 20 & 10 \\
Sepse apenas & 65 & 35 & 20 & 25 & 15 \\
Meio apenas(*) & 80 & 60 & 60 & 35 & 30 \\
Sobrenadante(**) & 85 & 85 & 75 & 55 & 55 \\
\hline
\end{tabular}

$\mathrm{n}=\mathbf{2 0}$ por grupo. $\mathbf{p}(\log -$ rank $)=\mathbf{0 , 0 0 3 7}$.

(*) grupo com sepse tratado com o meio de cultura somente.

(**) grupo com sepse tratado com o sobrenadante de cultura.

\section{REFERÊNCIAS}

(1) Angus DC,Linde-Zwirble WT, Lidicker J, Clermont G, Carcillo J, Pinsky MR. Epidemiology of severe sepsis in the United States: analysis of incidence, outcome, and associated costs of care. Crit Care Med. 2001; 29:1303-1310.

(2) Martin GS, Mannino DM, Eaton S , Moss Ml. The epidemiology of sepsis in the United States from 1979 through 2000. N Engl J Med. 2003; 348:1546-1554.

(3) Linde-Zwirble WT, Angus DC. Severe sepsis epidemiology: sampling, selection and society. Crit Care. 2004 Aug; 8 (4) :222-.Epub 2004Jul 9.

(4) Sands KE , Bates DW, Lanken PN, Graman PS, Hibberd PL, Kahn KL,et al. Epidemiology of sepsis syndrome in 8 academic medical centers. Academic Medical center Consortium Sepsis Project Working Group. JAMA.1997;278:234-240.

(5) Ministério da Saúde do Brasil. Indicadores e Dados Básicos - Brasil, 2005. Brasília: Ministério da Saúde; 2005. [citado 2007 maio 17]. Disponível em: http: tabnet.datasus.gov.br.

(6) Organizacion Pan Americana de la Salud; Organizacion Mundial de la Salud. La Salud em las Américas.Washington, D.C. OPAS-OMS; 2002; 2:125.

(7)Thurston AJ. Of blood, inflammation and gunshot wounds: the history of the control of sepsis. Clin Chem. 2003 Oct; 49(10):1696-707.

(8) David-Christopher. Christopher's textbook of surgery. 11 ed. Sabinston Jr MD, editor. Philadelphia: WB Saunders; 1977. Chapter 1.

(9) Selye H. The General Adaptation Syndrome in Textbook of Endocrinology. Acta 
Endocrinologica, Montreal,Canada; 1947.

(10) Brown SD. ARDS. History, definitions and physiology. Resp Care Med Clin N Amer. 1998 Dec; 4(4):167-82; vii.

(11) Muckart DJJ, Bhagwnjee S. American College of Chest Physicians-Society of Critical Care Medicine Consensus Conference: Definitions of the systemic inflammatory response syndrome and allied disorders in relation to critically injured partients. Crit Care Med. 1997; 25:1.789.

(12) Cheadle WG, Pemberton, M Robinson D, Livingnston DH, Rodriguez JL, Polk HC Jr. Lymphocyte subset response to trauma and sepsis. J Trauma. 1993; 35(6): 844-849.

(13) Mouta MF, Bianco AC, Maciel FM. Lymphopenia discriminates outcomes in a general ICU. Crit Care Med. 2003; 31(2 Suppl ): A130.

(14) Chinnaiyan AM, Huber-Lang M, Kumar-Sinha C, Barrette TR, Shankar-Sinha S, Sarma VJ, et al. Molecular Signatures of Sepsis, Multiorgan Gene Expression Profiles of Systemic Inflammation. Am J Pathol. 2001; 159(4):1199-1209.

(15) Tracey KJ. The inflammatory reflex. Nature . 2002 Dec 19-26;420(6917):853-9.

(16) Cohen J. The immunopathogenesis of sepsis. Nature. 220 Dec 19-26;420(6917):88591.

(17) Smith JW, Gamelli RL, Jones BS, Shankar S. Immunologic Responses to Critical Injury and Sepsis. J Int Care Med. 2006; 21(3):160-170.

(18) Levi M, Van der Poll T, Büller HR. Bidirectional Relation between Inflammation and Coagulation. Circulation. 2004; 109:2698-2704.

(19) Puyana JC, Pellegrini JD, De AK, Kodys K, Silva WE, Miller CL. Both T-helper-1 and T-helper-2-type lymphokines are depressed in posttrauma anergy. J Trauma. 1998; 44:1037-45.

(20) Fadok VA, Bratton DL, Konowal A, Freed PW, Westcott JY, Henson PM, . Macrophages that have ingested apoptotic cells in vitro inhibit proinflammatory cytokine production through autocrine/paracrine mechanisms involving TGF $b$, PGE2, and PAF. J Clin Invest. 1998; 101:890-898.

(21) Hotchkiss RS, Karl IE. The Pathophysiology and Treatment of Sepsis. NEJM. 2003; 348(2):138-50.

(22) Boos JC, Goon PK, Lip GY. The endothelium, inflammation and coagulation in sepsis. Clin Pharm \& Therap. 2006; 79:20-22.

(23) Rainer HT, Lam YL. Circulating Nucleic Acids and Critical Illness. Ann NY Acad Sci 2006; 1075:271-277.

(24) Anker P, Jachertz D, Stroun M, Brogger R, Lederrey C, Henri J, Maurice PA.The role 
of exracellular DNA in the transfer of information from $\mathrm{T}$ to B human lymphocytes in the course of immune response. J Immunogenet. 1980; 7:475-481.

(25) Weaver JG, Rouse MS, Steckelberg JM, Badley AD. Improved survival in experimental sepsis with an o5ally administered inhibitor of apoptosis. FASEB J. 2004; 18 : $1185-91$.

(26) Bernard GR, Vincent JL, Laterre PF, La Rosa SP, Dhainaut JF, Lopez-Rodriguez A, et al. Efficacy and Safety of Recombinant Human Activated Protein C for Severe Sepsis. NEJM. 2001; 344:699-709.

(27) Riedmann NC, Guo RF, Ward PA. A Key role of C5a/C5aR activation for the development of sepsis. J Leukoc Biol. 2003 Dec 1; 74(6): 966-970.

(28) Parker SJ, Watkins PE. Experimental models of Gram-negative sepsis. Brit J Surg. 2001; 88:22-30.

(29) Hotchkiss RS, Osmon SB, Chang KC, et al. Accelerated Lymphocyte Death in Sepsis Occurs by both the Death Receptor and Mitochondrial Pathways. J Immunol. 2005; 174: $5110-5118$.

(30) Hotchkiss RS, Chang KC, Grayson MH, Tinsley KW, Dunne BS,Davis CG, et al. Adoptive transfer of apoptotic splenocytes worsens survival, whereas adoptive transfer of necrotic splenocytes improves survival in sepsis. PNAS. 2003 May 27; 100(11)6724-29.

(31) Cantiello HF. Role of Actin Filament Organization in Cell Volume and Ion Channel Regulation. J Zool. 1997; 279: 425-35.

(32) SLazarides A, Lindberg U. Actin Is the Naturally Occurring Inhibitor of Deoxyribonuclease I. Proc Nat Acad Sci USA. Dec 1974; 71: 4742-47.

(33) Silva AP, Alves GG, Araújo A H, Sola-Penna M. Effects of Insulin and actin on phosphofructokinase activity and cellular distribution in skeletal muscle. An Acad Bras Cien. 2004, 76(3): 541-548.

(34) Du J,Wang X, Miereles C, Bailey JL, Debigare R, Zheng B et al. Activation of Caspase 3 is an initial step triggering accelerated muscle proteolysis in catabolic condition. J Clin Invest. 2004; 113(1):115-23.

(35) Erukhimov JA, Tang ZL, Johnson BA, Donahoe MP, Razzack JA, Gibson KF et al. Actin-containing Sera From Patients With Adult Respiratory Distress Syndrome Are Toxic to Sheep Pulmonary Endothelial Cells. Am J Respir Crit Care Med. 2000; 162:288-294.

(36) Jansen U, Eitner F, Ostendorf T. Extracellular Actin Impairs Glomerular Capillary Repair in Experimental Nesangioproliferative Glomerulonephritis. Nephron Exp Nephrol. 2003; 93:e-158-e 167.

(37) Vanders MC,Goldstein A, Wang Y.Thymosin B4 (Fx peptide) is a potent regulator of 
actin polymerization in living cells. Proc Nat Acad Sci USA. 1992 May; 89:4678-72.

(38) Goldstein A, Guha A, Zatz MM, ,Hardy MA, White A. Purification and biological activity of Thymosin, a Hormone of the Thymus Gland. Proc Nat Acad Sci USA.1972; 69(7):1800-1803.

(39) Malinda KM, Sidhu GS, Mani H ,Banaudha K, Maheshwari RK, Goldstein AL, Kleinman HK1. Thymosin B4 Accelerates Wound Healing. J Invest Dermatol. 1999;113:324-68.

(40) Ontogenesis of cell-mediated immunity in murine thymocytes and spleen cells and its acceletraion by thymosin, a thymic hormone. J Immunol. 1971; 106(3):773-780.

(41) Bock-Markette, Saxena A, White MD, Di Malo JM, Srivastava D Thymosin B4 activates integrin-linked kinase and promotes cardiac cell migration, survival and cardiac repair. Nature. 2004; 432(25): 466-472.

(42) Pott G, Lohman J, Zyndorf P, Geralch U. Vermingderung fibronectin im Plasma bei Patienten mit Sepsis und Schock. D med Welt. 1981;106(17): 532-538.

(43) Coulad JM, Jaqueson A, Labrouse J,Allard D.Plasma fibronectin and the adult respiratory distress syndrome. Presse Medicale. 1983 jul 9-16; 12(29):1825

(44) Pott G, Lohman J, Zyndorf P, Geralch U. Vermingderung fibronectin im Plasma bei Patienten mit Sepsis und Schock. D med Welt. 1981;106(17): 532-538.

(45) Rubli E, Bussard S, Frei E, Lundsgaard-Hansen P, Pappova E. Plasma fibronectin and associated variables in surgical intensivecare patients. Ann Surg. 1983; 197(3):310-317.

(46) Ko Sawashima, Shinya Mizuno, Yoko Mizuno-Horikawa. Expression of alfa-smooth muscle actin and fibronectin in tubulointersticial lesions of cats with chronic renal failure. Am J Vet Res. 2000; $61 \quad$ (9):1080-86.

(47) DvoraK HF, Kaplan AP Clark AF. Potential Functions of theclotting System in Wound Repair; Fibrin Formation. ClarK RAF. The Molecular and Cellular Biology of Wound Repair, Henson PM. New York: Plenum Press; 1988. Chapter 3.

(48) Bowness JM, Tarr AH. Increase in transglutaminase and its extracellular products in response to an inflamatory stimulus by lipopolyssacharide. Mol Cell Biochem. 1997; 169: 157-163.

(49) Chen R, Gao B, Huang C,Olsen B, Rotundo RF, Blumenstock F, Saba TM. Transglutaminase-mediated fibronectin multimerization in lung endothelial matrix in response to TNF-alfa. Am J Physiol Lung Cell Mol Physiol. 2000; 279:L161-174.

(50) Quan G, Choi JY, Lee DS, Lee SC. TGF-beta1 up-regulates transglutaminase two and fibronectin in dermal fibroblasts: a possible mechanism for thestabilization of tissue inflamation. Arch Dermatol Res. 2005. 296:84-90. 
(51) Sohn J, Kim TI, Yoon Y, Kim JY, Kim SYl. Novel transglutaminase inhibitors reverse the inflammation of allergic conjuntivitis. J Clin Invest. 2003; 111:121-128.

(52) Reed JC. BCL-2 and the regulation of Programmed Cell Death. J Cell Biol. 1994 Jan; 124(1-2):1-6.

(53) Bommhardt U, Chang KC, Swanson PE, Wagner TH, Tinsley KW, Karl IE, Hotchkiss RS. Akt Decreases Lymphocyte Apoptosis and Improves Survival in Sepsis. J Immunol. 2004; 172:7583-91.

(54) Plas DR, Rathmell JC, Thompson. Homeostatic control of lymphocyte survival: potential origins and implications. Nat Immunol. 2002 June; 3(6):515-521.

(55) Alpdogan O, Marcel RM van den Brink. IL-7 and IL-15: therapeutic cytokines for immunodeficiency. Trends Immunol. 2005 Jan; 26(1):56-64.

(56) Sawyers CL. Will Kinase Inhibitors Have a Dark Side. NEJM. 2006 july 3; 20:313-15.

(57) Oberholzer C, Oberholzer A, Clare-Salzler M, Moldawer LL : Apoptosis in sepsis: a new target for therapeutic exploration. FASEB J. 2001; 15:879-892.

(58) Miller JF. Immunological function of the thymus. Lancet. 1961; 2:748-749.

(59) Levey RH, Trainim N, Law LW. Evidence for function of Thymic Tissue in diffusion chambers implanted in neonatally thymectomized mice: preliminary report. J Exp Med. 1964; 119:177-94.

(60) Clark RWR. The Experimental Foundations of Modern Immunology. 4th ed.Local: J Winley e Sons; 1991. p. 275.

(61) Borzy MS, Hong R, Horowitz SD, Gilbert E, Kaufman D, De Mendonca W,et al. Fatal lymphoma after transplantation of cultured thymus in children with combined immunodeficiency disease. NEJM. 1979; 301( 11):565-568.

(62) Munno I, Pellegrino NM, Fumo G.Effects of a synthetic extract (thymopentin) on the immune system of lepromatous leprosy patients. Cytobios. 1987; 52:167-173.

(63) Badamchian M, Fagarasan MO, Danner RL Suffredini AF, Damavandy H, Goldstein $\mathrm{AL}$. Thymosin B4 reduces lethality and down-regulates inflammatory mediators in endotoxin-induced septic shock. Int Immunopharm. 2003; 3:1225-1233.

(64) Baumann CA, Badamchian M, Goldstein AL. Thymosin alfa-1 antagonizes dexamethasone and $\mathrm{CD}-3$ induced apoptosis of $\mathrm{CD} 4+\mathrm{CD} 8+$ thymocytes through the activation of cAMP and protein Kinase $\mathrm{C}$ dependent second messenger pathways. Mech Age Dev. 1997; 94: 85-101.

(65) Autores. Título do trabalho. Local: Editora; Ano. [cited ANO MES DIA]. Available from: www.regenerx.com/wt/page/diabetic-vitrectomy/. 
(66) Markert ML, Boeck A, Hale LP, Kloster AL, McLaughlin TM, Batchvarova MN, et al. Transplantation of thymus tissue in complete DiGeorge Sydrome. New Eng J Med. 1999; 341:1180-9.

(67) Wichterman KA, Baue AE, Chaudry IH. Sepsis and Septic Shock: A review of Laboratory Models and a Proposal. J Surg Res 1980; 29:189-20.

(68) Hsu SM, Raine L, Fanger H. Use of avidin- biotin-peroxidase complex (ABC) imunoperoxidase techniques; a comparision between $\mathrm{ABC}$ and unlabeled antibody (PAP) procedures. J Histoc Cytochem. 1981; 9(4):577-80.

(69) Guesdon JL, Ternynck T, Avrameas S. The use of avidin-biotin interaction in immunoenzymatic techniques. J Histochem Cytochem. 1979; 27(8):1131-39.

(70) Jerschke MG, Dagmar K, Hemdon DN. Insulinn Treatment Improves the Systemic Inflammatory Reaction to Severe Trauma. Ann Surg. 2004; 239(4):553-60.

\section{GLOSSÁRIO}

A

Ácidos nucléicos - DNA, RNA - Longas moléculas semelhantes a cadeias, que são encontradas nas células vivas, destinadas a conduzir informação genética e traduzi-la para a estrutura das proteínas. Existem dois tipos principais: DNA (ácido desoxirribonucléico) e RNA (ácido ribonucléico). O primeiro conduz as informações; o segundo as traduz.

Actina - Proteína abundante em vários tipos de células, de 43-Kd, que pode se aglomerar em polímeros para formar filamentos envolvidos na formação dos feixes do citoesqueleto, e na contratilidade celular.

Agenesia - Ausência congênita ou falha no desenvolvimento de parte do corpo.

Aglomerados de actina - Filamentos de actina que se unem para formar feixes.

AkT-PKB - Enzima do tipo serina-proteína-quinase (mobiliza grupamentos fosfato, ativada por PIP3, com papel chave na sinalização de sinais de sobrevivência celular).

AkT-ERK - Via de sinalização realizada pela fosforilação seqüencial de enzimas AKT e ERK envolvidas no controle do crescimento e sobrevivência celular.

American College of Chest Physicians - Colégio Americano de Cirurgiões Torácicos, dos Estados Unidos da América.

Aminas - Composto químico com propriedades básicas, contendo um grupo amino $\left(-\mathrm{NH}_{2}\right)$.

Anergia - Ausência de reação de hipersensibilidade a um determinado agente, em um indivíduo previamente apto a reagir contra esse agente; falha de linfócitos que foram 
previamente expostos a uma segunda exposição ao antígeno, com resultante perda ou depressão da função imunológica. Os indivíduos são chamados de "anérgicos" quando não conseguem montar esse tipo de resposta.

Anticorpo - Proteína produzida pelos linfócitos B que se ligam a uma molécula não própria do organismo (no-self); Qualquer molécula de imunoglobulina produzida em resposta direta a um antígeno (ou a um hapteno auto-acoplante) e que pode combinar especificamente, de modo não covalente e reversível com o antígeno que elicitou sua formação.

Anticorpos monoclonais - Anticorpos produzidos por populações de células originadas de um único linfócito $B$ fundido a uma célula tumoral, com grande capacidade proliferativa.Este anticorpo se liga sómente a um epitopo de uma única forma.

Anticorpos policlonais - Próvem da produção em animal (coelho, cabra, etc.), este anticorpo liga-se a vários epitopos.

Anticorpo primário - Anticorpo específico que reage com o antígeno presente no tecido.

Anticorpo secundário - Anticorpo dirigido contra um anticorpo desenvolvido por animal.

Anticorpo secundário biotinilado - Anticorpo secundário que se liga por alta afinidade à molécula de biotina.

Antissepsia - Procedimentos que impedem a multiplicação dos micróbios.

Antígeno - Molécula contra a qual um anticorpo é dirigido; qualquer agente que pode originar uma resposta imune. Alguns antígenos, porém, não a desencadeiam por si mesmos e são entendidos como antígenos "não-imunógenos".

Aminoácidos - Blocos monoméricos (monômeros) simples, que compõem as proteínas, consistindo de um átomo de carbono conectado a um grupo carboxil, um grupo amino, um átomo de hidrogênio e uma cadeia lateral distintiva ( $R$, na fórmula). Apresentam a fórmula geral $\mathrm{H}_{2} \mathrm{~N}-\mathrm{CHR}-\mathrm{COOH}$.

Apoptose - Processo ativo, programado, de morte celular, caracterizado por quebra do DNA cromossômico, condensação de cromatina e fragmentação de núcleo e de célula. $\mathrm{O}$ processo é freqüente nas células em proliferação e desempenha um papel crítico na manutenção do número de linfócitos em níveis fisiológicos. Tais fragmentos devem ser fagocitados, e levam à inflamação local. É caracterizado pela quebra do DNA cromossômico, condensação da cromatina e fragmentação, tanto do núcleo como do restante da célula.

ATP - Adenosina 5'-Trifosfato. Nucleotídeo formado a partir da oxidação da glicose. Devido à sua capacidade de armazenar energia, por meio de grupos fosfato, constitui a fonte primária de energia em todas as células. 
Baço - Órgão intra-abdominal único, sólido e encapsulado, que possui uma polpa vermelha, responsável pela destruição de hemácias envelhecidas, e uma polpa branca, com tecido linfóide, que responde aos antígenos trazidos pela corrente sangüínea.

Balb-C - Ver: nude.

BCL 2 - (proteína 2 de células de linfoma B) - Proteína membro da família de proteínas $\mathrm{BCL}$, que regulam o processo de morte celular, ligando-se à membrana mitocondrial e protegendo as células da apoptose. Descritas inicialmente em linfomas de células B.

Biotina - Molécula orgânica que serve como cofator necessário para reações de carboxilação. Esta molécula se liga com grande afinidade à etreptoavidina.

Blebbing - Formação de bolhas com fragmentos de membrana plasmática envolvendo restos celulares. 
Caspase - Família de enzimas proteases que quebram resíduos de ácido aspártico nas proteínas. Enzimas "cisteino-aspartato proteases", muito importantes no processo de morte celular por apoptose.

Catalisar - Acelerar reações químicas através de substâncias (catalisadores) que, em si próprias, não são alteradas pelas reações.

Ceco - Fundo de saco anatômico, onde inicia o intestino grosso.

Células dendríticas - Células com morfologia ramificada, presentes também em tecidos não linfóides, e com forte capacidade de estimular as respostas de linfócitos T. São originadas de precursores da medula óssea.

Células NK - (Natural Killer). Linfócitos não T e não B, com morfologia granular, importantes na destruição de células tumorais e células infectadas por vírus.

Cdk - (Cyclin dependent protein kinases). Enzima quinase que controla o ciclo celular dos eucariotas.

CD4 - Glicoproteína encontrada principalmente na membrana de linfócitos T. Atua como receptor de peptídeos de antígenos acoplados a moléculas do complexo HLA, provenientes das células apresentadoras de antígenos (fagócitos).

Choque - Estado patológico, conseqüente ao colapso da circulação sangüínea.

Ciclina D1 - Proteína pertencente à classe das ciclinas, que regulam a atividade das CdK e controlam a progressão do ciclo celular.

Citocinas - Também denominadas Interleucinas. São proteínas sintetizadas por células que afetam o comportamento de outras células. São chamadas de Linfocinas quando originadas de linfócitos, e Monocinas quando produzidas por monócitos. Exemplo: Interleucina 2 (IL 2).

Cisteína - Um dos aminoácidos encontrados nas proteínas.

Citocromos - Proteínas transportadoras de elétrons, que atuam na respiração, na fotossíntese e em outras reações de óxido-redução.

Citocromo C - Um dos transportadores de elétrons das mitocôndrias.

Citoesqueleto - Arcabouço formado primariamente por túbulos proteináceos que se ramificam pelo citoplasma, e que se ligam à membrana citoplasmática e a várias organelas. É responsável pela manutenção da forma e organização interna da célula, atuando na transmissão de sinais metabólicos e no transporte de vesículas pelo citoplasma. Nos organismos multicelulares, os elementos do citoesqueleto podem ligar uma célula a outra através da membrana plasmática e da matriz intercelular. 
Claudicação claudicar - Falhar no apoio da marcha, mancar (geralmente devido a um problema motor); "marcha claudicante".

Coagulopatias - Distúrbios da coagulação sangüínea, conseqüentes ao desequilíbrio entre fatores de coagulação e fatores anticoagulantes.

Componente humoral - Em solução ou suspensão, aqui se refere particularmente ao mecanismo imunológico envolvendo anticorpos e complementos, em contraste com a imunidade mediada por células.

Complemento, sistema complemento - Grupo de proteínas presentes no plasma sangüíneo dos vertebrados, que facilitam a fagocitose e atacam agentes patológicos extracelulares. A ativação das proteínas do complemento se faz numa cadeia de reações proteolítcas, na qual uma enzima ativa a seguinte. O complemento pode ser ativado espontaneamente ou pela ligação ao patógeno.

Complexo estreptavidina-peroxidadase - Estreptoavidina conjugada à peroxidase. Ligase à biotina do anticorpo secundário.

Confluência - Grau de contato entre duas células entre si, sem deixar áreas do fundo da placa de cultura descobertas.

Corticosteróides - Hormônios esteróides produzidos pela glândula adrenal, tais como a cortisona. Podem matar timócitos e linfócitos, por meio do mecanismo de apoptose. São usados em terapêutica como anti-inflamatórios e imunossupressores. Também regulam o metabolismo dos carboidratos, além de atuarem no metabolismo dos lipídios e proteínas.

Cultura de tecido - Manutenção de fragmentos de tecido in vitro, ou de explantes, ou órgãos e células dispersas, incluindo a cultura de linhagens celulares e manutenção e crescimento de pedaços de tecido explantado (planta ou animal) em cultura, fora do seu organismo original.

D

Diferenciação e maturação de linfócitos - Especialização dos lnfócitos. Processo que envolve alterações na expressão gênica, morfologia e bioquímica celular, tornando a célula especializada em algumas funções.

Dímero - Molécula composta por duas cadeias moleculares idênticas simples. A interação dinâmica entre proteínas diméricas é um importante mecanismo regulador de diversas funções biológicas.

Doença de Crohn - Doença que acomete qualquer ponto da parede do trato alimentar, causando edema inflamatório local, acompanhado de ulcerações.

DNA - Ver: ácidos nucléicos.

$\mathbf{E}$ 
Edema - Intumescimento causado pela entrada de fluido e células do sangue para o tecido, uma das características do processo inflamatório.

Elastase - Protease sérica que digere a elastina e o colágeno tipo IV, presentes nos tecidos de sustentação (matriz extracelular).

Endotélio - Epitélio dos vasos sangüíneos.

Enzimas - Proteínas originadas de células vivas capazes de produzir determinadas mudanças químicas sobre compostos orgânicos, com alta especificidade.

Epitélio - Camada de células que cobre a superfície do corpo e reveste a face interna dos órgãos.

Epitopo - Determinantes antigênicos que se relacionam com alta especificidade ao anticorpo.

Estresse oxidativo - Desequilíbrio entre a geração e a remoção dos produtos de reação do oxigênio com biomoléculas, que ocasiona lesão de mitocôndrias e oxidação de proteínas, com perda de suas funções.

Eucariotas, células eucariotas - Células que possuem núcleo com envelope, organelas citoplasmáticas e citoesqueleto, responsáveis pela produção de macromoléculas (proteínas) obtidas de espécies com raízes genéticas afastadas, que não variaram significativamente ao longo de um grande período no processo de evolução; macromoléculas com alto grau de invariância em sua estrutura primária (seqüência de aminoácidos), são ditas altamente conservadas; as com variação significativa são descritas como pouco conservadas evolutivamente.

Exógeno - Que se desenvolve ou se origina fora do organismo.

Explante - Fragmento de tecido transplantado de seu sítio original e mantido em meio artificial.

Exudatos - Fluido acumulado no sítio da inflamação ou lesão.

$\mathbf{F}$

Fagocitose, fagocitar - Ingestão de grandes partículas (por exemplo: bactéria) por uma célula. $O$ material ingerido pelas células fagocitárias ou fagócitos (macrófagos e neutrófilos) é destruído por enzimas presentes em vacúolos (lisossomas).

FAS-L - FAS-ligante. Molécula capaz de se ligar ao receptor FAS, presente na superfície de algumas células, e capaz de ativar as enzimas que levam ao mecanismo de morte por apoptose (caspases).

Fase I e Fase II de estudo terapêutico - Fases realizadas em humanos, posteriores ao estudo em animais, e relacionadas à verificação de segurança e eficácia clínica, 
respectivamente. Antecedem as fases de expansão em segmentos da população e distribuição do medicamento.

Fatores de crescimento - Polipeptídios que controlam o crescimento e a diferenciação de células animais.

Fatores de coagulação - Proteínas solúveis que, após uma série de reações enzimáticas, resultam na formação de fibrina e na adesão e agregação de plaquetas, que formam uma massa chamada trombo.

Fatores de sobrevivência celular - Substâncias capazes de suprimir a execução dos mecanismos de morte celular por apoptose.

Fatores de transcrição - Proteínas que regulam a atividade da enzima RNA polimerase (necessária para formação do RNA, em acordo com a informação presente no DNA).

Fibronectina - Principal proteína de adesão da matriz extracelular. Pode aglomerar-se com outras proteínas, por ação da enzima transglutaminase tecidual.

Fosforilação - Adição de um grupo fosfato a uma molécula.

G

Genoma - Quantidade total de genes portados pelo indivíduo ou célula.

Genótipo - A constituição genética (código genético) de um organismo ou célula, distintamente de sua expressão ou fenótipo.

Glicopeptídeos - Cadeias de peptídeos ligadas a açúcares (oligossacarídeos, com 2 a 10 átomos de carbono).

Glutamina - Um dos aminoácidos encontrados nas proteínas.

Glutaraldeído - Desinfetante e reagente usado para fixação de tecidos em microscopia eletrônica, com propriedade de formar ligações entre proteínas.

Granulócitos - Leucócitos polimorfonucleares. Leucócitos com citoplasma de aspecto granuloso (eosinófilos, neutrófilos, basófilos).

Glomerulonefrite - Inflamação das paredes capilares no glomérulo renal.

Glucocorticóides - Ver: corticosteróides.

H

$\mathbf{H}_{2} \mathbf{O}_{2}$ - Peróxido de Hidrogênio. Tipo de radical superóxido, ou espécie reativa de oxigênio. Ver: radicais livres de oxigênio; neutrófilos.

Heparina - Substância encontrada principalmente no fígado, músculos e pulmão, cuja 
função é diminuir a coagulação do sangue.

Hidrólise - Cisão e separação de moléculas, com a incorporação de moléculas de água aos fragmentos para produzir moléculas novas e menores.

Hipóxia - Baixa concentração de oxigênio em determinado tecido.

HLA - Human Leukocyte Antigen. Principal complexo de proteínas de membrana celular que confere identidade imunológica (própria ou exógena) reconhecida por outras células. Relaciona-se a segmentos da seqüência do DNA, que formam sistemas genéticos determinantes de aceitação ou rejeição de transplantes. Também está associado à intensidade de resposta imunológica durante a sepse, por também produzir peptídeos carreadores de resíduos microbianos, ingeridos por células do sistema imune, os quais, ao chegarem à face exterior da membrana celular, são reconhecidos como não pertencentes ao hospedeiro (no-self) pelos linfócitos (sistema de apresentação de antígenos).

Homeostático - Referente à homeostase; estado de equilíbrio do organismo vivo em relação à composição química dos seus líquidos e tecidos e às suas funções.

Hormônio - Substância química produzida por um órgão, conduzida pela corrente sangüínea, e capaz de produzir efeitos específicos em tecidos com receptores exclusivos.

Imunoglobulinas - Classe de proteínas presente em várias secreções e líquidos corporais.

Incursão respiratória - Movimento de expansão do tórax durante a inspiração.

Inflamação, resposta inflamatória - Acúmulo local de fluido, proteínas plasmáticas ou células brancas, iniciado por dano físico, infecção ou resposta imune local. A inflamação apresenta seus componentes, de acordo com o tipo de doença. Clinicamente apresenta-se com inchaço (edema), vermelhidão (aumento do fluxo sangüíneo), dor local, e perda da função do órgão lesado.

Insulina - Hormônio presente em vertebrados e invertebrados. Consiste em uma proteína simples formada por duas cadeias polipeptídicas - de 21 e 30 aminoácidos - mantidas juntas por ligações bissulfeto. Normalmente atua na membrana celular, promovendo a entrada de glicose na célula. É secretada na circulação sangüínea pelo pâncreas, quando a glicose atinge níveis insuficientes para o funcionamento das células. Tem propriedades mitógenas, devido ao fato de possuir segmentos semelhantes a fatores de crescimento, sendo freqüentemente adicionada ao meio de cultura de diversos tipos de células.

Integrinas - Proteínas que atravessam a membrana celular. Funcionam como mediadores de adesão a outras células e a proteínas matriciais extracelulares, na aderência da célula à matriz intersticial, nas interações adesivas entre linfócitos e células apresentadoras de antígenos e na migração de linfócitos e leucócitos nos tecidos.

Interferon gama - Citocina inflamatória produzida por células T CD4, células T CD8 e 
células matadoras naturais $(\mathrm{NK})$. Esta citocina tem como função primária a ativação de macrófagos, e também pode induzir resistência à replicação de vírus em outras células.

Interleucinas - Ver: citocinas.

In vitro - Expressão latina cuja tradução literal é "no vidro". Usada para se referir aos experimentos com células e tecidos vivos, mantidos funcionais, fora do corpo.

In vivo - Refere-se a experimentos ou condutas realizados no organismo vivo.

Imunodeficiências - Grupo de doenças herdadas ou adquiridas no qual algum aspecto da defesa do hospedeiro está ausente ou com defeito.

Isogênicos - Animais que possuem genótipos absolutamente idênticos (por exemplo: gêmeos idênticos).

Isquemia - Falta de circulação sangüínea (arterial) num órgão ou uma região do organismo.

$\mathbf{K}$

KiloDalton - Kd. Unidade de massa molecular. $1 \mathrm{Kd}=1.000$ daltons. $1 \mathrm{~d}=$ massa de um átomo de hidrogênio $(1,66$ X $20 \mathrm{~g})$.

$\mathbf{L}$

Leucócitos - Literalmente, “células brancas". Termo geral usado para designar qualquer célula encontrada no sangue, que não pertença à linhagem das hemácias (ou "células vermelhas"). Incluem os linfócitos, leucócitos polimorfonucleares e monócitos.

Ligações bissulfeto - Ligação química formada entre dois átomos de enxofre. Na química enzimática, tais ligações se formam entre resíduos de cisteína e mantêm reunidas cadeias polipeptídicas independentes ou partes separadas da mesma cadeia.

Ligação covalente - Ligação com maior estabilidade entre dois átomos, formada pelo compartilhamento de dois elétrons.

Ligacões químicas - Forças químicas que mantêm os átomos reunidos nas moléculas.

Ligadura cecal - Nó ou laço em volta do ceco, obstruindo sua luz e a circulação sangüínea.

Ligante - Qualquer molécula que se liga a outra. Normalmente usada como termo definido moléculas solúvel, como um hormônio ou neurotransmissor, que se liga a um receptor. A decisão entre ligante e receptor é algo arbitrário. Em geral, quando não envolve a transdução de sinal, o ligante tem a menor estrutura. Molécula ou complexo molecular que é reconhecido e se conecta a uma estrutura de receptor (geralmente na superfície celular).

Ligase - Classe de enzimas que catalisam a união de duas moléculas. Por exemplo, o DNA 
ligase, que liga dois fragmentos de DNA formando um laço fosfodiéster.

Linfócito - Célula sangüínea granulosa, com núcleo grande e pouco citoplasma, que ativa a resposta imune. Os linfócitos B produzem anticorpos e os linfócitos T são responsáveis pela imunidade mediada por células.

Linfoma - Tipo de câncer de células linfóides.

Linfóide - Característica relativa às células da linhagem dos linfócitos.

Linfopenia - Diminuição acentuada do número de linfócitos presentes no sangue circulante.

Lipopolissacáride (LPS) - Toxina bacteriana, geralmente obtida de Escherichia coli, capaz de ativar linfócitos do tipo B de maneira independente de antígenos.

Lisina - Um dos aminoácidos encontrados nas proteínas.

M

Macrófagos, macrófagos alveolares - Células fagocitárias grandes, mononucleares, com importante papel na imunidade. Podem apresentar antígenos a outras células, e atuar tanto na defesa humoral como na mediada por células. São originadas de precursores da medula óssea, têm capacidade migratória (quimiotaxia) e são encontradas em vários tipos de tecidos.

Matriz extracelular - Qualquer material secretado pela célula, que se deposita no meio à sua volta. Tecido frouxo, no qual a célula se sustenta . Termo geralmente aplicado à porção não celular dos tecidos animais. A matriz extracelular do tecido conectivo é particularmente extensa. Suas propriedades, nesse caso, determinam as propriedades do tecido. Em termos gerais, existem três maiores componentes da matriz: elementos fibrosos (particularmente Colágeno, Elastina, Reticulina), proteínas de ligação (Fibronectina e Laminina) e moléculas preenchedoras de espaço (Glicosaminoglicans). A matriz pode ser mineralizada para resistir à compressão (como no osso), ou dominada por fibras resistentes a tensão (como nos tendões). A lâmina basal das células epiteliais é um exemplo das mais encontradas. A matriz extracelular pode influenciar o comportamento das células de modo significativo, e pode determinar efeitos característicos sobre as células, quando retiradas do meio, e cultivadas in vitro.

Mecanismos conservados entre as espécies - Mecanismos de controle intracelular, realizados por proteínas codificadas em seqüências de nucleotídeos (código genético), que não mudaram significativamente ao longo do processo de evolução, e que apresentam semelhanças estruturais entre organismos afastados.

Meio de crescimento - Meio de rotina onde o número de células aumenta com o tempo (proliferação celular).

Meio de cultura - Mistura de sais inorgânicos e outros nutrientes capazes de manter a 
sobrevivência celular in vitro, por 24 horas.

Meio inflamatório - Setor em que se encontram células e substâncias químicas, associadas ao desenvolvimento da resposta inflamatória.

Meio de manutenção - Meio que preserva a sobrevivência celular sem crescimento (por exemplo: meio sem soro).

Mediadores inflamatórios - Substâncias químicas que estimulam a resposta inflamatória.

Mesentério - Dobra triangular do peritônio, que envolve o intestino delgado e o mantém posicionado na cavidade abdominal.

Metabólico - Referente aos processos químicos e energéticos que ocorrem nas células do organismo e que constituem a base das atividades vitais.

Microtrombos - Agregados microscópicos de fibrina e/ou hemácias, que obstruem os vasos da circulação capilar. Ver: fatores de coagulação.

Miocárdio - Músculo que compõe o coração.

Miosite de inclusão - Doença inflamatória crônica que acomete musculatura de pescoço e escápula.

Mitocôndria - Organela subcelular que contém agregados de enzimas metabólicas. Essencialmente, é o fornecedor primordial de energia para a célula.

Mitogênico, mitógeno - Qualquer substância capaz de induzir a célula a iniciar a síntese de DNA e a divisão celular.

Monócitos - Leucócitos granulosos, com núcleo lobulado, precursores dos macrófagos.

Monômero - Unidade básica de um polímero, por exemplo, aminoácidos em proteínas ou monossacarídeos em polissacarídeos.

Moléculas - Grupos de átomos unidos por ligações químicas; as principais unidades da estrutura química.

Mutação - Alteração num gene que conduz à produção de uma enzima ou outra proteína anormal (ou a ausência completa da produção de tal proteína).

$\mathbf{N}$

Necrose - Morte de uma célula ou tecido, causada por lesão química ou física, por infecção ou perda de suprimento sangüíneo. A necrose implica em extravasamento de detritos celulares - não envoltos por fragmentos de membrana celular - para o meio extracelular, o que não ocorre com a apoptose. 
Nefrite - Inflamação dos néfrons (unidade anatômica e funcional dos rins). Ver: glomerulonefrite.

Neutrófilos - Leucócitos grandes, amebóides, granulares, com núcleo lobulado e grânulos citoplasmáticos. Neutrófilos são células fagocitárias que podem ser coradas com corantes neutros como a eosina. Respondem ao estímulo quimiotático e é o maior tipo de célula envolvida nos estágios iniciais da inflamação (inflamação aguda). Contêm várias enzimas (lactoferrina, lisozima, mieloperoxidase). A estimulação da superfície celular de neutrófilos (por bactéria aderida a anticorpos ou a proteínas de fase aguda ou concanavalina A) leva a descarga respiratória na qual o consumo de oxigênio aumenta acentuadamente (em um pulso de vários minutos de duração), iniciando dentro de segundos da estimulação; muito do oxigênio é usado para formar radicais superóxidos, atuantes na lesão dos microorganismos fagocitados.

Nucleotídeo - Um dos corpos produzidos pela hidrólise das proteínas dos núcleos das células. Contêm uma base nitrogenada, uma molécula de açúcar e um ou mais grupos fosfato. Além de formarem os ácidos nucléicos, tomam parte em outras funções, como fornecimento de energia e transdução de sinais.

Nude - Camundongo com defeito genético (mutação), descoberto em 1962, que resulta em ausência de pêlos e de timo, com conseqüente déficit de linfócitos $T$. A resistência imunológica nesses animais é realizada principalmente por células NK, macrófagos e linfócitos B.

\section{$\mathbf{O}$}

Oxidação - Processo de combinação com oxigênio levando à perda de elétrons por esta molécula.

Óxido nítrico - Relaxante de musculatura vascular, de propriedades gasosas, produzido pelo endotélio, e que atua no receptor guanilato-ciclase intracelular. No sistema imune, é responsável por mecanismos de ataque citotóxicos a células infectadas por microorganismos.

Osteogênese - Processo de formação de células ósseas, a partir de osteoblastos.

$\mathbf{P}$

Peptídeo - Composto formado pela união de um ou mais aminoácidos.

Peritônio - Membrana serosa que reveste interiormente as paredes e os órgãos abdominais.

Peroxidase - Enzima que usa água oxigenada para oxidar os seus substratos. Estes substratos são desenhados de maneira que a sua oxidação seja detectada pela liberação de luz, formando um precipitado colorido.

Peroxidase endógena - Peroxidase produzida pelo próprio tecido. 
pH - Medida da concentração de íons hidrogênio de uma solução, inversamente correlacionada ao grau de acidez.

PIP3 - Fosfatidilinositol 3-fosfato. Segundo mensageiro formado pela fosforilação de PIP2 e lipídeos de membrana.

PKB-Akt - Ver: Akt.

PKB - Proteína quinase B; outra designação da enzima Akt.

Plasma - A parte líquida e coagulável do sangue e da linfa, onde se acham em suspensão as células destes.

Polimorfismo - Existência de variedades de formas diferentes. Polimorfismo genético é a variabilidade em um locus gênico (sítio do gene), no qual ocorrem variantes em uma freqüência maior que $1 \%$. O complexo HLA (histocompatibilidade principal) é o conjunto de genes mais polimórficos no ser humano (Ver: HLA).

Polipeptídeos - Polímeros formados por aminoácidos ligados em cadeia.

Polímero - Grande molécula formada a partir de unidades estruturais menores (monômeros).

Polimorfonucleares - Leucócitos com múltiplos núcleos e grânulos citoplasmáticos. Existem três tipos: Neutrófilos (que são fixados com corantes neutros), eosinófilos (fixados com eosina) e basófilos (com grânulos que fixam corantes básicos).

Ponto isoelétrico - Grau de acidez de um meio em que a proteína deixa ter carga elétrica, o que a correlaciona com determinadas propriedades bioquímicas.

Pressão Parcial Arterial de $\mathbf{C O}_{2}$ - Pressão que o gás dióxido de carbono exerce para se difundir nos tecidos orgânicos, independentemente da pressão exercida por outros gases.

Procariotas - Células caracterizadas por não possuírem núcleo, citoesqueleto ou organelas em citoplasma.

Proliferação de linfócitos - Reprodução de linfócitos; necessita da integridade de várias funções estruturas da matriz.

Prostaglandinas - Produtos lipídicos do metabolismo do ácido araquidônico com vários efeitos sobre os tecidos.

Protease - Enzimas que fragmentam componentes da matriz extracelular.

Proteína - Grande classe de compostos químicos orgânicos (constituídos de longas cadeias de aminoácidos); incluem as enzimas e outras importantes substâncias biológicas, como, por exemplo, as citocinas; polímero linear de aminoácidos ligados por laços peptídicos em uma seqüência específica. 
Proteínas de fase aguda - Também chamados de reagentes de fase aguda. Proteínas sintetizadas pelos hepatócitos (células hepáticas) e macrófagos, que surgem em quantidades elevadas no plasma, em resposta às citocinas (IL-6, IL-1) induzidas pelo dano tecidual ou infecção. Incluem a proteína $\mathrm{C}$ reativa, o fibrinogênio e a antitripsina. Suas funções ainda não estão bem compreendidas.

Proteíno-quinase - Enzima que fosforila um resíduo de determinado aminoácido (serina, treonina ou tirosina), em uma proteína.

Proteína quinase $\mathbf{C}$ - Enzima que fosforila resíduos de tirosina, importante nos processos de sinalização intracelular.

Quinases - Designação genérica de Fosfoquinase; enzima que catalisa a transferência de resíduos de fosfato (geralmente ATP) para um segundo substrato (por exemplo, serina / treonina quinase, que fosforila o resíduo do aminoácido serina ou treonina).

Quimiotaxia - Movimento de uma célula de um local para outro, sob a influência de um gradiente químico. Por exemplo, fagócitos podem ser atraídos por fragmentos de complemento que se difundem de um local de infecção.

$\mathbf{R}$

Radicais livres de oxigênio, radicais superóxidos - Termos usados com o mesmo sentido, seja para o ânion supeórxido $\mathrm{O}_{2}$, ou ácido fraco $\mathrm{HO}_{2}$. $\mathrm{O}$ superóxido é gerado tanto por procariotas como eucariotas, e é um importante produto dos neutrófilos (Ver: neutrófilos).

Reação de Stress - Conjunto de manifestações inespecíficas, do nível celular ao corpóreo, ao desgaste causado pela exposição do organismo a qualquer agente.

Receptores - Moléculas ligadas à membrana plasmática, que se ligam ou respondem a algo móvel (ligante) com alguma especificidade (por exemplo, receptores de acetilcolina, fotorreceptores de resíduos peptídicos).

Resposta imune - Resposta elaborada pelas células do sistema imune do hospedeiro a fim de se defender contra um agente invasor.

$\mathbf{S}$

Sangue periférico - Sangue presente no interior de veias e artérias.

Segundo mensageiro - Composto cujo metabolismo fica modificado após a interação entre um receptor e seu ligante. Funciona como transdutor de sinais ao regular outros processos intracelulares.

Septicemia - Presença, no sangue, de bactéria ou de seus produtos mórbidos (toxinas). 
Síndrome da Angústia Respiratória - Dificuldade de respirar, devido à infiltração de líquido surgido do próprio tecido pulmonar, após trauma ou choque, causando transtornos da oxigenação e da remoção de $\mathrm{CO}_{2}$ sangüíneos.

Sistêmica - Referente ao conjunto de órgãos e tecidos com funções análogas.

Sobrenadante - Fração líquida sobre os sedimentos durante centrifugação, ou sobre as células em cultura-substrato.

Society of Critical Care Medicine - Sociedade de Medicina Intensiva dos EUA.

Substrato - Molécula que é a alvo de ação de uma enzima; molécula que recebe a ação de uma enzima.

Susceptibilidade - Disposição para contrair enfermidade.

Superexpressão - Produção de determinada proteína em quantidade além da normal, obtida em animais transgênicos.

Teflon - Polímero plástico não tóxico, que pode formar membranas permeáveis apenas para líquidos.

T helper CD4 (helper T lymphocyte) - Linfócito derivado do timo, cuja presença é requerida para a produção de níveis normais de anticorpo pelos linfócitos B e também para o desenvolvimento adequado da imunidade mediada por células. Esta função de apoio requer a produção de citocinas como Interleucinas 4, 56 e interferon gama.

Timo - Órgão glandular, encapsulado, composto por tecido linfoepitelial e situado entre o esterno e o coração, necessário ao desenvolvimento dos linfócitos T. Sua remoção em recém-natos causa profunda diminuição da resposta imune e uma quase completa ausência de células T. Apresenta um grande volume na infância e, no adulto, é quase completamente substituído por tecido gorduroso. As células não linfóides do timo produzem hormônios (Timosinas) cujas ações não estão completamente esclarecidas.

Timócitos - Células linfóides em processo de maturação dentro do timo. Não confundir com células T.

Transcriptase reversa - Enzima que leva à formação de DNA em células do organismo infectado por certos vírus, a partir do RNA transmitido por estes.

Transdução - Conversão de um tipo de sinal para outro.

Transmembrana - Referente à qualidade de moléculas de proteínas que atravessam a membrana celular, com porções expostas nas duas superfícies.

Translocação, translocação bacteriana - Disseminação de bactérias originadas da luz intestinal para outros sítios do organismo, por via sangüínea, após atravessarem a parede 
intestinal inflamada.

Tricotomia - Depilar (preparação da pele para cirurgia).

Tirosina - Um dos aminoácidos encontrados nas proteínas.

Transgene - Gene ou fragmento de DNA de um organismo que foi incorporado de modo estável no genoma de outro organismo.

Transgênicos - Adjetivo descritor de organismo (geralmente planta ou animal) que contém um transgene.

Transglutaminase tecidual - Importante enzima extracelular que catalisa a formação de laço amida entre a glutamina e a cadeia lateral de resíduos de lisina em proteínas, com a eliminação de amônia. A ligação formada é estável e tem um importante papel em vários processos de montagem e

xtracelular.

Trauma - Conjunto de perturbações das funções fisiológicas, causado por ferimento ou contusão.

TGF- $\beta$ - Fator transformante de crescimento beta. Proteínas secretadas por células transformadas que podem estimular o crescimento de células normais, porém geralmente são inibidoras da proliferação de células animais. Embora, de fato, não seja capaz de transformar outras células, pode induzir a expressão de fenótipos malignizantes em células transformadas (malignizadas). $\mathrm{O}$ fator alfa, tem efeito angiogênico (estimula células endoteliais vasculares) em células transformadas por efeito de infecção viral. O fator beta estimula a cicatrização e, in vitro, é um inibidor de vários tipos de células.

TNF- $\alpha$ - Citocina produzida por macrófagos e linfócitos $T$, com múltiplas funções na resposta imune, inclusive, induzir o processo de morte celular.

$\mathbf{V}$

Viabilidade celular - Capacidade da célula sobreviver e exercer suas funções. $\mathbf{W}$

Wistar - Rato albino domesticado, usado para pesquisas biológicas. 
APÊNDICE 


